\title{
GLOBAL PRODUCTION SHARING AND RISING INEQUALITY: A SURVEY OF TRADE AND WAGES
}

\author{
Robert C. Feenstra \\ Gordon H. Hanson \\ Working Paper 8372 \\ http://www.nber.org/papers/w8372 \\ NATIONAL BUREAU OF ECONOMIC RESEARCH \\ 1050 Massachusetts Avenue \\ Cambridge, MA 02138 \\ July 2001
}

The views expressed herein are those of the authors and not necessarily those of the National Bureau of Economic Research.

(C) 2001 by Robert C. Feenstra and Gordon H. Hanson. All rights reserved. Short sections of text, not to exceed two paragraphs, may be quoted without explicit permission provided that full credit, including $\odot$ notice, is given to the source. 
Global Production Sharing and Rising Inequality:

A Survey of Trade and Wages

Robert C. Feenstra and Gordon H. Hanson

NBER Working Paper No. 8372

July 2001

JEL No. F16

\begin{abstract}
$\underline{\text { ABSTRACT }}$
We argue that trade in intermediate inputs, or "global production sharing," is a potentially important explanation for the increase in the wage gap between skilled and unskilled workers in the U.S. and elsewhere. Using a simple model of heterogeneous activities within an industry, we show that trade in inputs has much the same impact on labor demand as does skill-biased technical change: both of these will shift demand away from low-skilled activities, while raising relative demand and wages of the higher skilled. Thus, distinguishing whether the change in wages is due to international trade, or technological change, is fundamentally an empirical rather than a theoretical question. We review three empirical methods that have been used to estimate the effects of trade in intermediate inputs and technological change on wages, and summarize the evidence for the U.S. and other countries.
\end{abstract}

Robert Feenstra

Department of Economics

University of California

Davis, CA 95616

and NBER

rcfeenstra@ucdavis.edu

\author{
Gordon Hanson \\ IR/PS \\ University of California, San Diego \\ 9500 Gillman Drive \\ La Jolla, CA 92093-0519 \\ and NBER \\ gohanson@ucsd.edu
}




\section{Introduction}

One of the most widely-discussed public policy issues in the United States and many other industrial countries is the decline in the wages of less-skilled workers during the 1980's and 1990's, both in real terms and relative to the wages of more-skilled workers. The question is, what factors account for this change? One obvious explanation that comes to mind is increased competition from low-wage countries. Surprisingly, many economists researching this issue have come to the conclusion that trade is not the dominant - or even an important explanation for the shift in wages. They have instead looked to the massive influx of computers into the workplace, and other forms of technological change, as the explanation.

In this survey, we present a contrary point of view, and argue that international trade is indeed an important explanation for the increase in the wage gap. Our argument rests on the idea that an increasing amount of international trade takes the form of trade in intermediate inputs. This is sometimes called "production sharing" by the companies involved, or simply "outsourcing."1 Trade of this type affects labor demand in import-competing industries, but also affects labor demand in the industries using the inputs. For this reason, trade in intermediate inputs can have an impact on wages and employment that is much greater than for trade in final consumer goods. As we shall argue, trade in inputs has much the same impact on labor demand as does skill-biased technical change: both of these will shift demand away from low-skilled

1 Alternatively referred to as outsourcing (Katz and Murphy, 1992, Feenstra and Hanson, 1996), de-localization (Leamer, 1998), fragmentation (Deardorff, 2001; Jones and Keirzkowski, 1997, Arndt and Kierzkowski, 2000), intra-product specialization (Arndt, 1997 and 1998a,b), intra-mediate trade (Antweiler and Trefler, 1997), vertical specialization (Hummels, Ishii, and Yi, 2001), and slicing the value chain (Krugman, 1995), this phenomena refers to the geographic separation of activities involved in producing a good (or service) across two or more countries. The term "production sharing" was coined by management consultant Peter Drucker ("The Rise of Production Sharing," The Wall Street Journal, March 15, 1977), as we have adopted in our title. 
activities, while raising relative demand and wages of the higher skilled. Thus, distinguishing whether the change in wages is due to international trade, or technological change, is fundamentally an empirical rather than a theoretical question.

In the next section, we review the basic evidence that has been used to conclude that trade has not been a significant cause of U.S. wage changes. We argue that this evidence still leaves room for trade to be important, especially trade in intermediate inputs. Empirically, a good deal of trade is in intermediate inputs, and the impact of this on wages and other factor prices is quite different from that obtained with just trade in final goods. This is shown in section 3, where we present a simple model of trade in intermediate inputs. In section 4 we discuss various methods of estimating this model, and summarize the evidence for the U.S. and other countries. Conclusions and directions for further research are given in section 5.

\section{Changes in Wages and Employment}

The basic facts concerning wage movements in the United States are fairly well understood. ${ }^{2}$ For full-time U.S. workers between 1979 and 1995, the real wages of those with 12 years of education fell by $13.4 \%$ and the real wages of those with less than 12 years of education fell by $20.2 \%$. During the same period, the real wages of workers with 16 or more years of education rose by $3.4 \%$, so that the wage gap between less-skilled and more-skilled workers increased dramatically. ${ }^{3}$ To illustrate these trends, we can use data from the U.S. manufacturing sector for "nonproduction" and "production" workers. The former are often used as a proxy for

\footnotetext{
2 For a detailed discussion, see Katz and Autor (1999), whose wage figures we report below.

3 Only the highly skilled have had large real-wage gains. For the 1979-1995 period, real wages for those with 18 or more years of education rose by $14.0 \%$ and for those with 16 to 17 years of education rose by only $1.0 \%$.
} 
more-skilled workers, and the latter as a proxy for less-skilled workers. ${ }^{4}$ These trends are shown in Figure 1, which graphs the relative annual earnings of nonproduction/production workers in U.S. manufacturing, and Figure 2, which graphs their relative annual employment.

In Figure 1, we see that earnings of nonproduction relative to production workers in the U.S. moved erratically during the 1960's and 1970's, but then increased substantially during the 1980's and 1990's. Turning to Figure 2, we see that there has been a steady increase in the ratio of nonproduction to production workers used in U.S. manufacturing, with some leveling off recently. This increase in the supply of workers can account for the reduction in the relative wage of nonproduction workers from 1970 to the early 1980s, as shown in Figure 1, but is at odds with the increase in the relative nonproduction wage after that (Katz and Murphy, 1992). The rising relative wage should have led to a shift in employment away from skilled workers, along a demand curve, but it has not. Thus, the only explanation consistent with the facts is that there has been an outward shift in the demand for more-skilled workers since the mid-1980s, leading to an increase in their relative employment and wages (Katz and Autor, 1999).

The same decline in the relative wages of blue-collar workers during the 1980's and into the 1990's can be found for Australia, Canada, Japan, Sweden, and the United Kingdom (Freeman and Katz, 1994; Katz and Autor, 1999), ${ }^{5}$ and also for Hong Kong and Mexico (Cragg

4 The breakdown of workers according to whether or not they are engaged in production activity is made in the U.S. Annual Survey of Manufactures, and is used as a proxy for the occupational-class or skill-level of workers. While there are problems with using the production-nonproduction classification as a proxy for skill, there is evidence that in practice the classification shows similar trends as using skill categories (Berman, Bound and Griliches, 1994; Berman, Bound and Machin, 1998; Sachs and Shatz, 1994). The increase in the nonproductionproduction relative wage is only a small part of the total increase in wage inequality between more- and less-skilled workers that occurred during the 1980s. See Katz and Murphy (1992) and Katz and Autor (1999) for a discussion.

5 Rising wage inequality has been relatively modest in Australia, Canada, Japan, and Sweden. Among advanced countries, only the United Kingdom has had relative wage changes comparable to the United States (Machin, 1996). 
and Epelbaum, 1996; Hanson and Harrison, 1999; Hsieh and Woo, 1999). What factors account for these changes? Most widely cited are international competition from low-wage countries and skilled-biased technological change due to the increased use of computers, with the latter considered as the most important. ${ }^{6}$ There are at least three reasons why trade is thought to have played a rather minor role, and these are reviewed in the next sections.

\subsection{The Magnitude of Trade}

First, it is often noted that the magnitude of trade flows to and from the United States, especially with developing countries, is too small to lead to the observed wage changes. Indeed, for many industrial countries, the ratio of trade to GDP in 1970 was no higher than it was just before World War I. ${ }^{7}$ In the U.S., for example, the value of trade (an average of imports and exports) was $6.1 \%$ of GDP in 1913 , but only $4.1 \%$ in 1970 , rising to $8.8 \%$ in 1980 . Other industrial countries have higher levels of trade, but many (including France, Germany, Italy, and Sweden) show the same time-pattern as in the U.S. A few other countries, such as Australia, Denmark, Japan and the United Kingdom, still have not reached the trade/GDP ratio that they had in 1913. Krugman (1995, p. 331) uses these observations to conclude that: "it would be hard to argue that the sheer volume of trade is now at a level that marks a qualitative difference from previous experience." 8

6 See the surveys by Freeman (1995), Johnson and Stafford (1999), Richardson (1995), Wood (1995), and Feenstra (1998) and the volumes by Bhagwati and Kosters (1994) and Collins (1998).

7 Data on the ratio of trade to GDP is provided in Feenstra (1998), who also computes the ratios of merchandise trade to merchandise value-added, as discussed below.

8 Krugman $(1995,2000)$ provide the theoretical argument for why a small share of trade in the U.S. makes it unlikely that trade can account for the change in wages. For an alternative views, see Deardorff (2000), Leamer (2000), and Panagariya (2000). 
But the ratio of trade to GDP does not tell the whole story. All industrial countries have had increasing shares of their economies devoted to services rather than merchandise (i.e., manufacturing, mining and agriculture). To make a better comparison of trade with overall production, we should measure merchandise goods in both the numerator and the denominatori.e., compare merchandise trade to merchandise value-added. When this is done, there are still two countries for which this ratio was larger in 1913 than in 1990 (Japan and the United Kingdom) and one other for which this ratio changed little (Australia). But all other industrial countries have experienced substantial growth in trade relative to merchandise value-added between 1913 and 1990: this ratio has increased by about one-third for Denmark and Norway; by three-quarters for Canada; has doubled for France, Germany, Italy, and Sweden; and has nearly tripled for the United States, rising from $13.2 \%$ in 1913 to $35.8 \%$ in 1990 . We conclude that merchandise trade has indeed grown substantially relative to the production of these commodities in many advanced countries.

Has the composition of merchandise trade changed over time? Various evidence indicates that intermediate goods play an increasingly important role in trade. One approach is to look at "processing trade," which is defined by customs offices as the import of intermediate inputs for processing, and subsequent re-export of the final product. This activity has grown enormously in China, for example, for which Hong Kong often serves as an intermediary. For example, between 1988 and 1998, processing exports grew from $\$ 12.4$ billion to $\$ 97.2$ billion, or from about one-third to over one-half of total Chinese exports (Feenstra and Hanson, 2001, Table 1). This outward processing serves newly industrialized countries in Asia, but also developed countries such as the U.S., Japan and Europe. Between the industrialized countries, too, there has been an increase in processing trade. Görg (2000, Table 1) reports on the increase 
in U.S. processing trade with the European Union between 1988 and 1994. He finds that U.S. processing imports into these countries (as a share of their total U.S. imports) increased slightly from $17.7 \%$ to $19.8 \%$, but this same ratio increased more significantly from $13.7 \%$ to $23.7 \%$ for the "periphery" countries of Greece, Ireland, Portugal and Spain.

In addition to processing trade, the total amount of imported intermediate inputs can be estimated by using the purchases of each type of input, and multiplying this by the economywide import share for that input. Summing this over all inputs used within each industry, we obtain estimated imported inputs, which can then be expressed relative to total intermediate input purchases. Feenstra and Hanson (1999) perform this calculation for U.S. manufacturing industries, and find that imported inputs have increased from $6.5 \%$ of total intermediate purchases in 1972 to $8.5 \%$ in 1979 , and $11.6 \%$ in 1990 .

Campa and Goldberg (1997) make the same calculation for Canada, Japan, the United Kingdom, and the United States, and their results are shown in Table 1.9 The United States shows a doubling of the share of imported inputs between 1975 and 1995 for all manufacturing, though it is still at a low level compared to Canada and the United Kingdom, where over 20\% of inputs were purchased from abroad in 1993. The United Kingdom, especially, shows a large absolute increase in foreign outsourcing. For individual industries, the chemical industry has a lower share of imported inputs than overall, whereas machinery (non-electric and electric) and transportation equipment have higher shares in these three countries. The machinery and transportation industries have especially rapid growth in imported inputs, with the shares

\footnotetext{
9 Imported intermediate inputs have also been computed for nine OECD countries by Hummels, Ishii, and Yi (2001). They find that $30 \%$ of OECD exports are attributable to imported intermediate inputs used in their production.
} 
doubling or even tripling between 1974 and 1993. The exception to these observations is Japan, where the share of imports in these heavy industries is lower than in overall manufacturing, and has generally been falling. With this single exception, the increased use of imported inputs is a characteristic feature of many industrial countries over the past two decades.

\subsection{Changes in Import Prices}

The second reason why some authors have argued that international trade is not a significant factor in explaining the movement in wages has to do with the behavior of import and export prices. In widely cited work, Lawrence and Slaughter (1993) have shown that the movement of prices across industries seems to contradict the movement of relative wages. ${ }^{10}$ In order for international competition to be the cause of the fall in the relative wage of less-skilled workers, we should see that prices of the least-skill-intensive goods - such as apparel - have fallen relative to other goods. While relative prices for apparel goods fell in the 1970's, they were stable in the 1980's (Leamer, 1998). Prices for other less-skilled-intensive goods actually rose in the 1980's.

This can been seen from Table 2, which is taken from the work of Lawrence and Slaughter (1993) and Lawrence (1994). For each country, the first row is a weighted average of the change in manufacturing prices over the 1980s, where the weights are the industry's share of total manufacturing employment of nonproduction workers. The second row is again the weighted average of the change in prices over the 1980s, but now using the industry's share of employment of production workers. For U.S. import prices, for example, we can see that when

\footnotetext{
10 See Slaughter (2000a) for a discussion of literature on relative-price changes.
} 
industries are weighted by their production workers, the average price increase is higher than when we weight by non-production workers. The same pattern can be seen by comparing the rows for other industrial countries. This means that some of the industries that use the most production - or less-skilled - workers are those with the highest price increases. This finding led Lawrence and Slaughter (1993) to conclude that the price movements, due to international competition, could not explain the wage movements.

However, if we accept that industries are engaged in importing intermediate inputs, then this suggests a different way to look at the price data. Rather that comparing prices across different industries, depending on their skill-intensity, it now makes sense to compare import and domestic prices within each industry. The types of goods being imported within each industry

(e.g., auto parts) are not the same as those being sold domestically (e.g., finished autos). Indeed, as U.S. firms find imported inputs at increasingly lower prices - through outsourcing activities that they used to do at home - we would expect to see that U.S. prices within each industry should be rising relative to import prices. In terms of Table 2, we should be comparing the price changes across columns rather than across rows. We see that for the United States during the 1980s it is indeed the case that domestic prices rose faster than import prices, and the same is true for Japan and Germany. These price movements are entirely consistent with a model of foreign outsourcing, whereby the United States and other industrial countries are continually seeking lower-cost sources of supply. Based on this logic, there is no "contradiction" at all between the movement of prices and relative wages.

\subsection{Employment Changes Within and Between Industries}

The third piece of empirical evidence comes from decomposing the shifts in the relative employment of less-skilled workers into those occurring within industries, and those occurring 
between industries. According to this line of reasoning, international trade should have the effect of moving workers between sectors, as industries expand or contract in response to foreign competition. In contrast, new technology, such as the increased use of computers, would change the ratio of more-skilled to less-skilled workers employed within each sector. Some evidence on this within versus between industry distinction in contained in Table 3 , which is taken from Berman, Bound and Griliches (1994), and Bernard and Jensen (1997).

Part A of Table 3 decomposes the change in the relative employment and relative wages of nonproduction workers into those that occurred within and between industries. We can see that in the period 1979-1987, the relative employment of nonproduction workers increased by slightly more than one-half of one percent per year $(0.546 \%)$, with about two-thirds of that $(0.362 \%)$ explained by within industry movements. On the wages side, the relative annual earnings of nonproduction workers increased by about seven-tenths of a percentage point per year $(0.719 \%)$, with more than half of that change $(0.410 \%)$ explained by within industry movements. The conclusion suggested by Berman, Bound and Griliches (1994) is that trade cannot be a dominant explanation for the wage and employment shifts, because the between industries movements are smaller than the within industry movements.

However, that conclusion raises the question of what is occurring within these industries, and whether that shift could itself be related to international trade. Bernard and Jensen (1997) have obtained some suggestive evidence on this point, by doing the same decomposition but using plant-level data rather than industry-level data. This is shown in Part B of Table 3. Looking again at the period 1979-1987, we can see that nearly one-half of the relative increase in the employment of non-production workers $(0.392 \%)$ occurred due to shifts between plants $(0.177 \%)$, and more than one-half of the increase in the relative wage of non-production 
workers $(0.536 \%)$ is also explained by movements between manufacturing plants $(0.315 \%)$.

Furthermore, Bernard and Jensen have found that the plants experiencing the greatest increase in relative nonproduction employment and earnings are precisely those that are engaged in export activity.

The results of Bernard and Jensen provide prima facie evidence that trade has had an impact on factor demand and wages. In order to understand what these linkages are, we present in the next section a simple model of outsourcing, that builds upon the key insight of their empirical work: the heterogeneity of production activities within industries.

\section{A Simple Model of Outsourcing}

Of the many activities that take place within any industry, let us identify just three: the production of an unskilled-labor intensive input, denoted by $\mathrm{y}_{1}$; the production of a skilled-labor intensive input, denoted by $\mathrm{y}_{2}$, and the "bundling together" of these two goods into a finished product. The two intermediate inputs are produced at home and also traded internationally; by including such trade in intermediate inputs, our model therefore incorporates outsourcing or "production sharing." We shall simplify the analysis, however, by assuming that the production of these two inputs and the "bundling" activity are always performed at home; thus, we are ruling out corner solutions where one of these activities is done entirely abroad. In reality, corner solutions such as this are very common. For example, many U.S. firms export intermediate inputs to the maquiladora plants in Mexico, where assembly of the inputs and other 
production activities take place there rather than in the U.S.11 A model of production sharing that emphasizes the movement of entire activities across countries is developed by Feenstra and Hanson (1996). Our theoretical treatment in this survey is simplified by only examining the marginal movement of production across countries, as induced by changes in prices. Despite this simplification, we will be able to motivate much of the empirical work in this area.

We note that theoretical models of production sharing are only starting to take hold within international economics: in addition to Feenstra and Hanson (1996), examples include the papers gathered in Arndt and Keirzkowski (2001), as well as Kim and Mieszkowski (1995), Leamer (1996), Xu (2000), Yi (2000), and Marjit and Acharyya (forthcoming). ${ }^{12}$ This concept is also used in economic sociology (Gereffi and Korzeniewicz, 1994), geography (Dicken et al, 2001; Yeung, 2001) and other social sciences, where production sharing is referred to by the more general name "commodity chains." A commodity chain consists of the sequence of activities involved in the manufacture of a product, from initial development through to production, marketing and sales, especially as these activities cross international boundaries. In these disciplines, commodity chains are seen as an integral part of the development process for countries that are still industrializing, i.e. a country's position in the commodity chain will impact its standard of living. While we will be taking a less grand view, it will still be the case in our simplified model that production sharing has a substantial impact on wages.

11 For a discussion of the Mexican maquiladora, see Feenstra and Hanson (1997). The export of inputs from the U.S. for assembly overseas also occurs in other countries under the U.S. "offshore assembly" program: see Feenstra, Hanson and Swenson (2000).

12 Other models that emphasize the movement of production activities across countries in a product-cycle framework, and the effect on wages, include Dinopoulos and Segerstrom (1999), Glass and Saggi (2001) and Zhu (2000a), with corresponding empirical work by Zhu (2000b). The reader is also referred to the collection of papers in the June 2001 issue of the Journal of International Economics, 54(1). 
We will suppose that the two inputs $\mathrm{y}_{\mathrm{i}}, \mathrm{i}=1,2$, are each produced using unskilled labor $\left(\mathrm{L}_{\mathrm{i}}\right)$, skilled labor $\left(\mathrm{H}_{\mathrm{i}}\right)$, and capital $\left(\mathrm{K}_{\mathrm{i}}\right)$, with concave and linearly homogeneous production functions,

$$
y_{i}=f_{i}\left(L_{i}, H_{i}, K_{i}\right), \quad i=1,2 .
$$

For example, the unskilled-labor intensive input $\mathrm{y}_{1}$ might represent the activities done within a factory, while the skilled-labor intensive input $y_{2}$ might represent the research and development activities within the industry, as well as marketing and after-sales service. These are both needed to produce the final manufacturing product. But some of the activities done within the factory can instead be outsourced, i.e. imported from abroad; and conversely, the services associated with research, development and marketing can be exported to support production activities abroad. We therefore let $\mathrm{x}_{1}<0$ denote the imports of input 1 , and $\mathrm{x}_{2}>0$ denote the exports of input 2. For convenience, we choose the exported intermediate input as the numeraire, so we will hold this price fixed (at unity), and let $\mathrm{p}$ denote the price of the imported input $\mathrm{x}_{1}$.

The production of the final manufacturing good is given by $\mathrm{y}_{\mathrm{m}}=\mathrm{f}_{\mathrm{m}}\left(\mathrm{y}_{1}-\mathrm{x}_{1}, \mathrm{y}_{2}-\mathrm{x}_{2}\right)$, where this production function "bundles together" the amounts of goods 1 and 2 available, and is also concave and linearly homogeneous. We ignore any additional labor and capital inputs used in this bundling activity, so that the total factor usage in the manufacturing industry is,

$$
\mathrm{L}_{1}+\mathrm{L}_{2}=\mathrm{L}_{\mathrm{m}}, \quad \mathrm{H}_{1}+\mathrm{H}_{2}=\mathrm{H}_{\mathrm{m}}, \quad \mathrm{K}_{1}+\mathrm{K}_{2}=\mathrm{K}_{\mathrm{m}} .
$$


We can now solve for the optimal output in the industry, which includes the three activities. With perfect competition, the value of output from the final good, plus net trade, will be maximized subject to the resource constraints:

$$
\begin{aligned}
\mathrm{F}_{\mathrm{m}}\left(\mathrm{L}_{\mathrm{m}}, \mathrm{H}_{\mathrm{m}}, \mathrm{K}_{\mathrm{m}}, \mathrm{p}_{\mathrm{m}}, \mathrm{p}\right) \equiv \max _{\mathrm{x}_{\mathrm{i}}, \mathrm{L}_{\mathrm{i}}, \mathrm{H}_{\mathrm{i}}, \mathrm{K}_{\mathrm{i}}} & \mathrm{p}_{\mathrm{m}} \mathrm{f}_{\mathrm{m}}\left(\mathrm{y}_{1}-\mathrm{x}_{1}, \mathrm{y}_{2}-\mathrm{x}_{2}\right)+\mathrm{px}_{1}+\mathrm{x}_{2}, \\
& \text { subject to (1), (2), }
\end{aligned}
$$

where $\mathrm{p}_{\mathrm{m}}$ is the price of the final good, and $\mathrm{p}$ is the price of the imported intermediate input. Note that the optimization problem in (3) does not require that trade is balanced on an industryby-industry basis, i.e. we do not require that $\mathrm{px}_{1}+\mathrm{x}_{2}=0$. Of course, there will be some balance of trade constraint for the economy overall, but we ignore that here. The value of the industry production function in (3) can be thought of as value-added for the industry, i.e. nominal output including exports $\mathrm{x}_{2}$ less the value of intermediate inputs $\mathrm{px}_{1}$.

Problem (3) can be easily illustrated, as in Figure 3, where we show the production possibility frontier between inputs 1 and 2 , and several isoquants of the final good $\mathrm{y}_{\mathrm{m}}$. For the purpose of illustration we now add the extra condition that trade in the inputs is balanced $\left(\mathrm{px}_{1}+\right.$ $\mathrm{x}_{2}=0$ ), so that the output of the final good is maximized on the isoquant that is tangent to the balanced trade line. At initial prices, for example, the industry produces inputs at A, and then trades to B. With a drop in the relative price of the imported input, the industry shifts production towards the skilled-labor intensive activity at A', and then trades to B', obtaining a higher output $\mathrm{y}_{\mathrm{m}}$. All this will look very familiar to most readers: the only special feature of Figure 3 is that we think of these activities taking place within a single manufacturing industry. 
The function $F_{m}\left(L_{m}, H_{m}, K_{m}, p_{m}, p\right)$ is linearly homogeneous in prices, so we can alternatively write it as $\mathrm{p}_{\mathrm{m}} \mathrm{F}_{\mathrm{m}}\left(\mathrm{L}_{\mathrm{m}}, \mathrm{H}_{\mathrm{m}}, \mathrm{K}_{\mathrm{m}}, 1, \mathrm{p} / \mathrm{p}_{\mathrm{m}}\right)$. Thus, a natural measure of real value-added or real output is,

$$
\mathrm{Y}_{\mathrm{m}} \equiv \mathrm{F}_{\mathrm{m}}\left(\mathrm{L}_{\mathrm{m}}, \mathrm{H}_{\mathrm{m}}, \mathrm{K}_{\mathrm{m}}, 1, \mathrm{p} / \mathrm{p}_{\mathrm{m}}\right)
$$

This measure of output is nearly the same as $\mathrm{y}_{\mathrm{m}}$, except it now includes net exports. Provided that the underlying production functions $\mathrm{f}_{\mathrm{i}}, \mathrm{i}=1,2, \mathrm{~m}$, are increasing and concave, then the function $\mathrm{F}_{\mathrm{m}}$ will also be increasing and concave in $\left(\mathrm{L}_{\mathrm{m}}, \mathrm{H}_{\mathrm{m}}, \mathrm{K}_{\mathrm{m}}\right)$. We can think of $\mathrm{F}_{\mathrm{m}}$ as an "aggregate production function" for the industry.

The difficulty with using this "aggregate production function" for any empirical or theoretical work is that it implicitly holds fixed the level of labor and capital used in the industry, i.e. at those levels given by the constraints in (2). Instead, we would like to think of labor, and possibly capital too, as being optimally adjusted in response to changes in factor prices. To reflect this, we make use of the cost function that is dual to (4). First, we can define a short-run cost function, obtained when the level of capital and output are fixed:

$$
\mathrm{C}_{\mathrm{m}}\left(\mathrm{w}, \mathrm{q}, \mathrm{K}_{\mathrm{m}}, \mathrm{Y}_{\mathrm{m}}, \mathrm{p} / \mathrm{p}_{\mathrm{m}}\right) \equiv \underset{\mathrm{L}_{\mathrm{m}}, \mathrm{H}_{\mathrm{m}}}{\min } \mathrm{wL}_{\mathrm{m}}+\mathrm{qH}_{\mathrm{m}} \text {, subject to (4), }
$$

where $\mathrm{w}$ is the wage of unskilled labor and $\mathrm{q}$ is the wage of skilled labor. Alternatively, we can define a long-run cost function, obtained when labor and capital are both chosen optimally:

$$
\mathrm{C}_{\mathrm{m}}\left(\mathrm{w}, \mathrm{q}, \mathrm{r}, \mathrm{Y}_{\mathrm{m}}, \mathrm{p} / \mathrm{p}_{\mathrm{m}}\right) \equiv \min _{\mathrm{L}_{\mathrm{m}}, \mathrm{H}_{\mathrm{m}} \mathrm{K}_{\mathrm{m}}} \mathrm{wL}_{\mathrm{m}}+\mathrm{qH}_{\mathrm{m}}+\mathrm{rK} \text { m, subject to (4). }
$$

where $r$ is the rental on capital. 
Both of these cost functions have been used empirically, as we discuss in the following sections. Before turning to this material, however, it is well worth exploring a few theoretical properties. In particular, if we add the condition that marginal cost equals product prices, and then allow prices to change, what will be the impact on factor prices? In Figure 3, for example, we showed how a fall in the relative price of imports $\mathrm{p}$ would raise final output $\mathrm{y}_{\mathrm{m}}$, but what is the corresponding impact on factor prices? In the remainder of this section we explore this question theoretically, making use of the long-run version of the cost function.

If both types of labor and capital are being optimally chosen for the industry overall, as in (6), then they must also be optimally chosen within each of the activities $i=1,2$. So consistent with (6), we can also define the long-run cost functions for the disaggregate activities within the industry:

$$
C_{i}\left(w, q, r, Y_{i}\right) \equiv \min _{L_{i}, H_{i}, K_{i}} w_{i}+q H_{i}+r K_{i} \text {, subject to (1), for } i=1,2 \text {. }
$$

Since the activity production functions in (1) are assumed to be linearly homogeneous, then the activity-level cost functions in (7) will be homogeneous of degree one in $Y_{\mathrm{i}}$. This implies they can be written as $\mathrm{C}_{\mathrm{i}}\left(\mathrm{w}, \mathrm{q}, \mathrm{r}, \mathrm{Y}_{\mathrm{i}}\right)=\mathrm{Y}_{\mathrm{i}} \mathrm{c}_{\mathrm{i}}(\mathrm{w}, \mathrm{q}, \mathrm{r})$, where $\mathrm{c}_{\mathrm{i}}(\mathrm{w}, \mathrm{q}, \mathrm{r})$ is the unit-cost function (equal to marginal cost or average cost).

Then the zero-profit conditions for activities 1 and 2 can be written as:

$$
\mathrm{p}=\mathrm{c}_{1}(\mathrm{w}, \mathrm{q}, \mathrm{r}), \quad 1=\mathrm{c}_{2}(\mathrm{w}, \mathrm{q}, \mathrm{r})
$$

These conditions must hold in order for the locally produced inputs $y_{i}, i=1,2$, to be competitive with those available from abroad, at the prices $p$ and unity, respectively. Totally differentiating 
(8) using the familiar Jones' (1963) algebra, we can express the percentage change in factor prices $\hat{\mathrm{w}}, \hat{\mathrm{q}}$, and $\hat{\mathrm{r}}$ as functions of the percentage change in the import price $\hat{\mathrm{p}}$ :

$$
\hat{\mathrm{p}}=\theta_{1 \mathrm{~L}} \hat{\mathrm{w}}+\theta_{1 \mathrm{H}} \hat{\mathrm{q}}+\theta_{1 \mathrm{~K}} \hat{\mathrm{r}}, \quad 0=\theta_{2 \mathrm{~L}} \hat{\mathrm{w}}+\theta_{2 \mathrm{H}} \hat{\mathrm{q}}+\theta_{2 \mathrm{~K}} \hat{\mathrm{r}}
$$

where $\theta_{\mathrm{ij}}$ is the cost-share of factor $\mathrm{j}$ in activity $\mathrm{i}$, with $\sum_{\mathrm{j}} \theta_{\mathrm{ij}}=1$. Treating the change in the import price $\hat{\mathrm{p}}$ as exogenous, (9) gives two equations with which to determine three unknown factor prices changes $-\hat{\mathrm{w}}, \hat{\mathrm{q}}$, and $\hat{\mathrm{r}}$. In general, these factor price changes will be difficult to pin down with only two equations. In terms of Figure 3, when production shifts towards the skilled labor intensive activity, from A to A', we do not know in general how factor prices are affected. But there are some simplifying assumptions we can make which allow us to determine these.

\section{Case 1 - Equal Cost Shares of Capital}

As in Feenstra and Hanson (1996), we can assume that capital has equal cost shares in the two industries, so that $\theta_{1 \mathrm{~K}}=\theta_{2 \mathrm{~K}}$. Using this, we take the difference between the two equations in (9) to obtain,

$$
\hat{\mathrm{p}}=\left(\theta_{1 \mathrm{~L}}-\theta_{2 \mathrm{~L}}\right) \hat{\mathrm{w}}+\left(\theta_{1 \mathrm{H}}-\theta_{2 \mathrm{H}}\right) \hat{\mathrm{q}}=\left(\theta_{1 \mathrm{~L}}-\theta_{2 \mathrm{~L}}\right)(\hat{\mathrm{w}}-\hat{\mathrm{q}})
$$

where the second equality follows since with equal cost shares of capital, the total cost shares of labor are also equal, so that $\left(\theta_{1 \mathrm{~L}}+\theta_{1 \mathrm{H}}\right)=\left(\theta_{2 \mathrm{~L}}+\theta_{2 \mathrm{H}}\right) \Rightarrow\left(\theta_{1 \mathrm{~L}}-\theta_{2 \mathrm{~L}}\right)=-\left(\theta_{1 \mathrm{H}}-\theta_{2 \mathrm{H}}\right)$. With activity 1 assumed to be unskilled-labor intensive, we have that $\left(\theta_{1 \mathrm{~L}}-\theta_{2 \mathrm{~L}}\right)>0$. Thus, (10) says that a decrease in the price of imported intermediate input, $\hat{\mathrm{p}}<0$, leads to a decrease in the relative wage of unskilled labor, $(\hat{\mathrm{w}}-\hat{\mathrm{q}})=\hat{\mathrm{p}} /\left(\theta_{1 \mathrm{~L}}-\theta_{2 \mathrm{~L}}\right)<0$. 
These results are illustrated in Figure 4, where we graph the iso-curves of $p=c_{1}(w, q, r)$ and $1=\mathrm{c}_{2}(\mathrm{w}, \mathrm{q}, \mathrm{r})$. With the wages of unskilled and skilled labor labeled on the axis, we are implicitly holding fixed the rental on capital, r. Now suppose that there is a fall in the price $p$ of activity 1, which is unskilled labor intensive. In Figure 4, this will shift inwards the iso-cost line of that activity, and as shown, will lead to a fall in the relative wage of unskilled labor (from A to B). There will be some additional change in the rental on capital, but under our assumption of equal cost share of capital in the two industries, this will lead to an equi-proportional shift in the two iso-cost curves and therefore have no further effect on the relative wage. Thus, the drop in the price of the imported inputs leads to a fall in the relative wage (w/q) of unskilled labor.

We can also ask what happens to the price of the final good $\mathrm{p}_{\mathrm{m}}$. Let $\mathrm{c}_{\mathrm{m}}(\mathrm{p}, 1)$ denote the unit-cost function that is dual to $f_{m}\left(y_{1}, y_{2}\right)$, where recall that the price of activity 2 is unity. Then the price of the final good satisfies $\mathrm{p}_{\mathrm{m}}=\mathrm{c}_{\mathrm{m}}(\mathrm{p}, 1)$, so that $\hat{\mathrm{p}}_{\mathrm{m}}=\theta_{\mathrm{m} 1} \hat{\mathrm{p}}$, where $\theta_{\mathrm{m} 1}$ is the cost-share of input 1 in the final product. Thus, with a fall in the price of imported inputs, $\hat{\mathrm{p}}<0$, the price of the final good also falls but by less, $\hat{\mathrm{p}}<\hat{\mathrm{p}}_{\mathrm{m}}<0$. Stated differently, the price of the final good relative to imported inputs rises, $\hat{\mathrm{p}}_{\mathrm{m}}-\hat{\mathrm{p}}>0$. This in fact is what happened in the U.S. and other industrial countries, as shown in Table 2, where the change in domestic prices exceeds the change in import prices over 1980-1990. Our theoretical model therefore confirms that this price movement is consistent with the fall in the relative wage of unskilled labor.

\section{Case 2 - The Unskilled-Labor Intensive Activity is also Capital Intensive}

A second case, emphasized by Sachs and Shatz (1998), is where activity 1 uses more unskilled labor, $\left(\theta_{1 \mathrm{~L}}-\theta_{2 \mathrm{~L}}\right)>0$, and also more capital, $\left(\theta_{1 \mathrm{~K}}-\theta_{2 \mathrm{~K}}\right)>0$; think of factory production, for example. They suppose that the price of the imported input is constant, $\hat{\mathrm{p}}=0$, but that the 
rental price on capital increases, $\hat{\mathrm{r}}>0$, because capital is leaving the country. In Figure 5, this will lead to an inward shift in both iso-cost curves, but since activity 1 uses more capital, a larger shift in that curve. Thus, the factor-price equilibrium will shift from A to B in Figure 5, where the wage of unskilled labor has fallen. We are not sure whether the wage of skilled labor rises or falls, but in any case, we obtain a fall in the relative wage (w/q) of unskilled labor. ${ }^{13}$ Intuitively, because activity 1 uses both unskilled labor and capital intensively, when capital leaves it is then unskilled labor that suffers. In this case, the cause of the change in wages is an outflow of capital from the country. ${ }^{14}$

Notice that the change in relative wages occurs without any change in the price of the imported input or the final good. We might expect, though, that there will be some impact on the price of a nontraded good. Denoting the zero-profit condition for a nontraded good by $\mathrm{p}_{\mathrm{n}}=$ $\mathrm{c}_{\mathrm{n}}(\mathrm{w}, \mathrm{q})$, we can totally differentiate this expression to obtain:

$$
\hat{\mathrm{p}}_{\mathrm{n}}=\theta_{\mathrm{nL}} \hat{\mathrm{w}}+\theta_{\mathrm{nH}} \hat{\mathrm{q}}
$$

where $\theta_{\mathrm{nj}}$ is the cost-share of factor $\mathrm{j}=\mathrm{L}, \mathrm{K}$. For simplicity, we assume the nontraded good uses no capital in production. In terms of Figure 5, the nontraded good would have an additional isocost line (not drawn) that goes through both points A and B. The question we wish to determine

13 To verify this, use $\hat{p}=0$ in (9) and then solve for $\hat{\mathrm{w}}$ and $\hat{\mathrm{q}}$ as: $\hat{\mathrm{w}}=-\hat{\mathrm{r}}\left(\theta_{2 \mathrm{H}} \theta_{1 \mathrm{~K}}-\theta_{1 \mathrm{H}} \theta_{2 \mathrm{~K}}\right) /\left(\theta_{1 \mathrm{~L}} \theta_{2 \mathrm{H}}-\theta_{1 \mathrm{H}} \theta_{2 \mathrm{~L}}\right)$, and $\hat{\mathrm{q}}=\hat{\mathrm{r}}\left(\theta_{2 \mathrm{~L}} \theta_{1 \mathrm{~K}}-\theta_{1 \mathrm{~L}} \theta_{2 \mathrm{~K}}\right) /\left(\theta_{1 \mathrm{~L}} \theta_{2 \mathrm{H}}-\theta_{1 \mathrm{H}} \theta_{2 \mathrm{~L}}\right)$. Combining these, we readily obtain $\hat{\mathrm{w}}-\hat{\mathrm{q}}=-\hat{\mathrm{r}}\left(\theta_{1 \mathrm{~K}}-\theta_{2 \mathrm{~K}}\right) /\left(\theta_{1 \mathrm{~L}} \theta_{2 \mathrm{H}}-\right.$ $\theta_{1 \mathrm{H}} \theta_{2 \mathrm{~L}}$ ), which is negative when $\hat{\mathrm{r}}>0$ under our assumptions that activity 1 is intensive in both unskilled labor and capital.

14 Sachs and Shatz (1998, pp. 220-221) emphasize that this capital outflow need not be foreign direct investment, in which a domestic firms takes ownership of capital abroad. Rather, the domestic capital could simply be sold to a foreign firm (which would not show up as foreign direct investment). 
is whether the change in factor prices from A to B implies an increase or a decrease in the price of the nontraded good.

To answer this, let us consider two extreme cases: where the non-traded good uses only unskilled labor, or only skilled labor. In the first case, the iso-cost line for the nontraded good would be vertical in Figure 5, i.e. each level of the unskilled wage w would correspond to a unique value for costs $c_{n}(w)$. In that case, the movement of the factor-price equilibrium from $\mathrm{A}$ to B would require a shift in the iso-cost line of the non-traded good to the left, and a corresponding fall in the price of the nontraded good (exactly like the fall in unskilled wages). Alternatively, if the nontraded good uses only skilled labor, then its iso-cost line would be horizontal in Figure 5, so that each level of the skilled wage q corresponds to a unique value for costs $\mathrm{c}_{\mathrm{n}}(\mathrm{q})$. In this case, we are unsure whether the movement of the equilibrium from A to B implies a rise or fall in the price of the nontraded good. If the iso-cost line of activity 1 shifts down sufficiently more (i.e. activity 1 is much more capital intensive than activity 2 ), then it is visually apparent that point B would imply a higher wage for skilled labor, and a higher price for the nontraded good if it uses enough of this factor. In fact, Sachs and Shatz (1998) argue for the U.S. that nontraded goods are indeed skilled-labor intensive relative to manufacturing overall. In that case, the exit of capital, and increase in the relative wage of skilled labor, can be expected to lead to a rise in the price of the nontraded good. Conversely, if the nontraded good is more unskilled-labor intensive, then its price will fall.

The evidence for the U.S. is that skilled-labor intensive nontradables experienced a rise in price during the 1980s, whereas unskilled-labor intensive nontradables experienced a fall in prices, consistent with these theoretical predictions. As we shall discuss in section 4.3, Harrigan and Balaban (1999) and Harrigan (2000) find that these changes in nontradables prices are 
highly correlated with change in relative wages, but this leaves open the question of causality: are the prices of nontradables driving the relative wages or, as we have suggested here, are the relative wages driving the prices of nontradables? We have shown that the exit of capital in an open economy can quite plausibly have the effect of raising both the relative wage of skilled labor and the price of skill-intensive nontradables, and lowering both the relative wage of unskilled labor and the price of unskilled-intensive nontradables, which is consistent with evidence for the U.S. during the 1980s.

\section{Results from Empirical Studies}

Summarizing our argument so far, the decision of companies to purchase intermediate inputs from overseas will most certainly affect their employment at home, and can be expected to differentially affect skilled versus unskilled workers. With firms in industrial countries facing a higher relative wage for unskilled labor than that found abroad, the activities that are outsourced would be those that use a large amount of unskilled labor, such as assembly of components and other repetitive tasks. Moving these activities overseas will reduce the relative demand for unskilled labor in the industrial country, in much the same way as replacing these workers with automated production. This means that outsourcing has a qualitatively similar effect on reducing the relative demand for unskilled labor within an industry as does skilledbiased technological change, such as the increased use of computers. Thus, determining which of these is most important is an empirical question. We will examine three methods that have been used to estimate the effects of trade versus technological change on wages and employment. 


\subsection{Estimation of Demand for Skilled Labor}

The first empirical method estimates industry production functions, such as (4), and attempts to determine which factors affect the relative demand for skilled labor. The starting point is to consider the short-run cost function that is dual to the industry production function, $\mathrm{C}_{\mathrm{m}}\left(\mathrm{w}, \mathrm{q}, \mathrm{K}_{\mathrm{m}}, \mathrm{Y}_{\mathrm{m}}, \mathrm{p} / \mathrm{p}_{\mathrm{m}}\right)$, as derived in (5). Notice that we have included the relative price of imported inputs in this cost function, since it also appears in the production function (4). More generally, any structural variables that shift the production function and therefore affect costs should be included as arguments. We will denote these variables by the vector $\mathrm{z}$; in addition to the price of imported inputs, this can include expenditures on computers and other new types of capital equipment. We therefore rewrite the cost function in (5) as $C_{m}\left(w, q, K_{m}, Y_{m}, z\right)$.

The next step is to choose a functional form for costs. A convenient choice is the translog cost function, which was introduced by Diewert (1974, p. 139) and initially used in the international trade literature by Kohli $(1978,1991)$. This function is written in a general notation as,

$$
\begin{array}{r}
\ln C=\alpha_{0}+\sum_{\mathrm{i}=1}^{\mathrm{I}} \alpha_{\mathrm{i}} \ln \mathrm{w}_{\mathrm{i}}+\sum_{\mathrm{k}=1}^{\mathrm{K}} \beta_{\mathrm{k}} \ln \mathrm{x}_{\mathrm{k}}+\frac{1}{2} \sum_{\mathrm{i}=1}^{\mathrm{I}} \sum_{\mathrm{j}=1}^{\mathrm{I}} \gamma_{\mathrm{ij}} \ln \mathrm{w}_{\mathrm{i}} \ln \mathrm{w}_{\mathrm{j}} \\
+\frac{1}{2} \sum_{\mathrm{k}=1}^{\mathrm{K}} \sum_{\ell=1}^{\mathrm{K}} \delta_{\mathrm{k} \ell} \ln \mathrm{x}_{\mathrm{k}} \ln \mathrm{x}_{\ell}+\sum_{\mathrm{i}=1}^{\mathrm{I}} \sum_{\mathrm{k}=1}^{\mathrm{K}} \phi_{\mathrm{ik}} \ln \mathrm{w}_{\mathrm{i}} \ln \mathrm{x}_{\mathrm{k}}
\end{array}
$$

where $\mathrm{w}_{\mathrm{i}}$ denotes the wages of the optimally chosen inputs $\mathrm{i}=1, \ldots, \mathrm{I}$, and $\mathrm{x}_{\mathrm{k}}$ denotes either the quantities of the fixed inputs or outputs $\mathrm{k}=1, \ldots, \mathrm{K}$, or any other shift parameters. In terms of the cost function in (11), there are just two optimally chosen factors - skilled and unskilled labor - 
while capital and output are treated as fixed in the short run. In order to ensure that the cost function in (12) is linearly homogeneous in wages, we impose the requirements, ${ }^{15}$

$$
\sum_{i=1}^{I} \alpha_{i}=1 \text { and } \sum_{i=1}^{I} \gamma_{i j}=\sum_{j=1}^{I} \gamma_{i j}=0
$$

The usefulness of the translog function comes from computing its first derivatives, $\partial \operatorname{lnC} / \partial \ln w_{\mathrm{i}}=\left(\partial \mathrm{C} / \partial \mathrm{w}_{\mathrm{i}}\right)\left(\mathrm{w}_{\mathrm{i}} / \mathrm{C}\right)$. Because $\partial \mathrm{C} / \partial \mathrm{w}_{\mathrm{i}}$ equals the demand for the chosen input $\mathrm{i}$, it follows that $\left(\partial \mathrm{C} / \partial \mathrm{w}_{\mathrm{i}}\right)\left(\mathrm{w}_{\mathrm{i}} / \mathrm{C}\right)$ equals the payments to factor $i$ relative to total costs, which we denote by the cost-shares $\mathrm{s}_{\mathrm{i}}$. Thus, differentiating (12) with respect to $\ln \mathrm{w}_{\mathrm{i}}$, we obtain,

$$
\mathrm{s}_{\mathrm{i}}=\alpha_{\mathrm{i}}+\sum_{\mathrm{j}=1}^{\mathrm{I}} \gamma_{\mathrm{ij}} \ln \mathrm{w}_{\mathrm{j}}+\sum_{\mathrm{k}=1}^{\mathrm{K}} \phi_{\mathrm{ik}} \ln \mathrm{x}_{\mathrm{k}}, \quad \mathrm{i}=1, \ldots, \mathrm{I} .
$$

Given annual data on factor cost shares, wages, and fixed inputs and outputs, this set of linear equations can be estimated over time for a given industry to obtain the coefficients $\gamma_{\mathrm{ij}}$ and $\phi_{\mathrm{ik} .}{ }^{16}$ Alternatively, the equations can be estimated for a single year, or the change between two years, by pooling data across industries. In the latter case, we are assuming that the same cost function applies across the industries. Despite this strong assumption, the cross-industry approach is popular and we shall follow it here.

15 Without loss of generality, we also impose the symmetry restrictions $\gamma_{\mathrm{ij}}=\gamma_{\mathrm{ji}}$ and $\delta_{\mathrm{jk}}=\delta_{\mathrm{kj}}$.

16 Generally, the dependent variables in the system (14) sum to unity, which means that one of the equations can be derived from the others. Under these conditions, one of the equations is dropped before the system (14) is estimated. In addition, the cross-equation symmetry restrictions $\gamma_{\mathrm{ij}}=\gamma_{\mathrm{ji}}$, and homogeneity restrictions $\Sigma_{\mathrm{j}} \gamma_{\mathrm{ij}}=0$, should be tested, and imposed if accepted. Additional tests can be used to check that the estimated cost function is concave in wages. 
Returning now to the notation $\mathrm{C}_{\mathrm{m}}\left(\mathrm{w}, \mathrm{q}, \mathrm{K}_{\mathrm{m}}, \mathrm{Y}_{\mathrm{m}}, \mathrm{z}\right)$, we have two chosen inputs - skilled and unskilled labor. Focusing on the share equation for skilled labor, it will depend on wages for both types of labor, as well capital, output, and all other structural variables, z. When (14) is estimated by pooling data across industries, as in Berman, Bound and Griliches (1994) for example, it is felt the cross-industry variation in wages has little information: wages differ across industries principally due to quality-variation of workers, so we do not expect high-wage industries to economize on those (high-quality) workers. Accordingly, the wage terms are typically dropped from the right of (14) when pooling data across industries. This leaves just fixed capital, output, and other structural variables. Taking the difference between two years, the estimation equation for the wage-share of skilled labor $\left(\mathrm{s}_{\mathrm{Hm}}\right)$ in industries $\mathrm{m}=1, \ldots, \mathrm{M}$ becomes:

$$
\Delta \mathrm{s}_{\mathrm{Hm}}=\phi_{0}+\phi_{\mathrm{K}} \Delta \ln \mathrm{K}_{\mathrm{m}}+\phi_{\mathrm{Y}} \Delta \ln \mathrm{Y}_{\mathrm{m}}+\phi_{\mathrm{z}}{ }^{\prime} \Delta \mathrm{z}_{\mathrm{m}}, \quad \mathrm{m}=1, \ldots, \mathrm{M}
$$

where $\mathrm{z}_{\mathrm{m}}$ denotes the vector of structural variables that shift costs, and $\phi_{\mathrm{m}}$ is the corresponding vector of coefficients. In particular, when the wage-share of skilled labor is increasing, we are interested in determining how much of that increase is due to changes in capital, output, and the structural variables.

Estimates of (15) for 447 industries within the U.S. manufacturing sector, over 19791990, are shown in Table 4. The data are from the NBER Productivity Database (Bartelsman and Gray, 1996, which is available at http:/www.nber.org/nberces/). In these regressions we use nonproduction labor as a proxy for skilled labor, so the dependent variable is the change in the share of nonproduction labor in total wages within each industry. Over all manufacturing industries, the nonproduction wage share increased from $35.4 \%$ to $42.4 \%$ between 1979 and 1990 , for an annual growth of $0.4 \%$ per year. 
The specifications in Table 4 are similar to those in Berman, Bound and Griliches (1994), Autor, Katz and Krueger (1998), and Feenstra and Hanson (1999). They include as regressors the shipments of each industry (as a proxy for output), the capital/shipments ratio, foreign outsourcing (imported intermediate inputs as a share of total materials purchases), the shares of computers and other high-tech capital in the total capital stock, and the share of expenditures on computers in total investment. The share of computers and other high-tech capital in the total capital stock is constructed using either ex post rental prices, or ex ante rental prices. ${ }^{17}$ In contrast, the share of computer spending in investment is obtained from the Census of Manufactures, which simply asked firms to report what percentage of new investment was devoted to computers. This variable has been used previously by Berman, Bound and Griliches (1994) and Autor, Katz and Krueger (1998). We feel that measuring computers as a share of the total capital stock is preferable. All variables are at the industry level and all, except the computer investment share, are measured as annual changes. All regressions are weighted by the industry share of the total manufacturing wage bill.

In column (1) of Table 4, we report the mean values of the dependent and independent variables for 1979-1990, and, following this, the regression coefficients in columns (2)-(4). Each regression uses alternative measures of the computer and other high-technology shares. In all the regressions, we see that outsourcing has a positive impact on the nonproduction share of

17 Multiplying the ex post rental price of each capital asset in an industry times the stock of that asset, and summing over all types of capital, equals observed payments to capital (i.e. value of shipments less payments to labor and materials). The share of computers in the capital stock is measured by taking the computer stock times its rental price, divided by the sum over all assets of each asset stock times its rental price. The ex ante rental prices are constructed by omitting capital gains on each asset, and using a "safe" rate of return. See Feenstra and Hanson (1999) for further details on these rental prices and the computer and other high-tech shares. 
the wage bill, as does the computer share. By multiplying the regression coefficients by the mean values for the change in each variable, we obtain the contributions of each to the total change in the nonproduction wage share, shown in column (5). We see that outsourcing accounts for $15-24 \%$ of the shift towards nonproduction labor. ${ }^{18}$

The results for computers depend on the specification. Measuring computer services and other high-tech capital as a share of the capital stock, using ex post rental prices, we see they account for $13 \%$ of the shift towards nonproduction labor. Measuring these shares using ex ante rental prices, we see that that computers and other high-tech capital explain only $8 \%$ of this shift. In both cases, the contribution of computers and other high-tech capital is less than the contribution of outsourcing. In contrast, when computers are measured by their share of investment (and the high-technology capital share is also included), we see that these variables account for $31 \%$ of the shift toward nonproduction labor, which exceeds the contribution of outsourcing. Thus, whether outsourcing is more or less important than computers depends of whether the latter are measured as a share of the capital stock, or as a share of investment. It is fair to conclude that both these variables are important explanations of the shift towards nonproduction labor, with their exact magnitudes depending on how they are measured.

In related work, Morrison Paul and Siegel (2000) find a negative correlation between the demand for less-educated labor and high-tech capital, R\&D investment, imports (as a share of output), and service purchases (i.e., domestic outsourcing), and a positive correlation between

18 Autor, Katz, and Krueger (1998) obtain smaller estimates for the impact of outsourcing on the nonproduction wage share. This appears to be due to the fact that they also include as regressors industry measures of imports and exports, which are highly correlated with imported intermediate inputs. 
the demand for more-educated labor and high-tech capital, R\&D investment, and imports. Their estimated impact of high-tech capital and $R \& D$ investment on skill upgrading is greater than that for imports or domestic outsourcing of services.

From these results, it appears that foreign outsourcing from U.S. manufacturing is associated with the increased relative demand for skilled labor, as predicted by the theory outlined in section 3. One important question is what form this outsourcing takes. It may occur through foreign direction investment (FDI), as multinationals move production of parts and components or product assembly abroad, or it may occur through a shift in contracting practices, in which firms replace domestic production of intermediate inputs with imports purchased from arms-length suppliers located abroad. The first case appears to be consistent with what has occurred in the U.S. automobile and semiconductor industries, while the second case appears to be consistent with what has occurred in the U.S. footwear and personal-computer industries.

Slaughter (2000b) finds that during the 1980's FDI was not an important channel for moving U.S. jobs abroad or for skill upgrading at home. Between 1977 and 1989, employment in majority-owned affiliates of U.S. multinational enterprises (MNEs) fell, as it did in the U.S. parents of these plants. Similar to U.S. manufacturing plants, affiliates of U.S. MNEs spent the 1980's shifting employment towards nonproduction workers and raising the capital intensity of production. Slaughter estimates a specification similar to (15), in which he includes as regressors shipments, the capital/shipments ratio, and the ratio of economic activity in foreign affiliates of U.S. MNEs to economic activity in U.S. manufacturing plants. The last variable captures the extent to which U.S. MNEs are transferring production abroad. For several measures of economic activity in foreign affiliates, there is a weak negative correlation between the change in the nonproduction wage share and the change in foreign production transfer by 
U.S. MNEs. Combined with the results in Feenstra and Hanson (1999), these results suggest that

FDI is not the means through which outsourcing has induced skill upgrading in U.S.

manufacturing. 19 In related work, Blonigen and Slaughter (1999) find that inward FDI in U.S. manufacturing during the 1980's, such as the construction of Japanese auto plants and other facilities, also did not contribute to skill upgrading in U.S. manufacturing industries. ${ }^{20}$

The United States is by no means the only country that engages in outsourcing. Many European nations are outsourcing, as well as industrialized Asian countries including Japan, Hong Kong, Korea and Taiwan (Ng and Yeats, 1999). In one study for the United Kingdom, Anderton and Brenton (1997) measure outsourcing by imports from low-wage countries. They find that such imports can account for about $40 \%$ of the rise in the wage bill of skilled workers of 1970-83, and approximately one-third of their increase in relative employment.

Over the last several decades, Japan has steadily moved production activities abroad, investing in both low-income and high-income countries. For firms in the Japanese electronics industry, overseas employment now greatly exceeds employment in Japan. These production shifts have coincided with skill upgrading at home. Since the early 1970's Japanese manufacturing industries have had a steady increase in the relative employment and relative total compensation of more-educated workers. Applying a specification similar to (15) to data on Japanese manufacturing plants over the period 1965-1990, Head and Ries (2000) find a strong

19 This finding may be driven by the fact that through the 1980's U.S. MNEs continued to concentrate their foreign operations in OECD countries, where their production activities are similar to those in U.S. manufacturing plants. During the 1990's, this pattern began to change, as FDI by U.S. MNEs shifted towards emerging economies. Future foreign production transfer by U.S. MNEs may then be associated with skill upgrading in the United States. See Blomstrom, Fors, and Lipsey (1997) and Lipsey (1999).

20 See also Brainard and Riker (1997) and Riker and Brainard (1997). Lipsey (1994) and Feliciano and Lipsey (1999) discusses employment and compensation practices of foreign MNEs in the United States. 
positive correlation between the change in a firm's nonproduction wage share and the change in a firm's share of employment in low-income countries. This suggests that as Japanese manufacturing firms move production to low-wage countries they raise the skill intensity and the demand for skilled labor at home. The correlation between the nonproduction wage share and the employment share in high-income countries, in contrast, is statistically insignificant in most cases. $^{21}$

During the 1960's and 1970's, Hong Kong produced and exported labor-intensive manufactures, such as apparel, textiles, footwear, toys, and consumer electronics. Since China began to open its economy to foreign trade and investment in the late 1970's, Hong Kong has begun to specialize in business services related to trade and investment in China. Over the last two decades, many Hong Kong manufacturing firms have moved their production facilities to China, and to the neighboring province of Guandong in particular, which they manage from headquarters in Hong Kong (Sung, 1997). Hong Kong firms typically supply plants in China with raw materials and often ship the goods through Hong Kong for final processing before exporting them to a final destination. As Hong Kong has shifted production to China, manufacturing has become a less important part of the Hong Kong economy, declining from 24\% of GDP in 1980 to 7\% of GDP in 1996 (Enright et al., 1997).

Hsieh and Woo (1999) find that outsourcing from Hong Kong to China has been associated with an increase in the relative demand for skilled labor in Hong Kong. Between

21 Head and Ries also find that when Japanese firms move production to low-income countries they raise input purchases from these countries, but when they move production to high-income countries they do not. One interpretation of these results is that when Japanese firms move production to low-wage countries they mainly outsource low-skill tasks, which raises skill intensity at home, but when they move production to high-wage 
1981 and 1996, both the relative wage and relative supply of more-educated workers rose in Hong Kong, which suggests that there was an increase in the relative demand for skilled labor. The extent of skill upgrading in Hong Kong manufacturing was dramatic. The share of nonproduction workers in Hong Kong manufacturing employment rose from $13.1 \%$ in 1976 to $47.0 \%$ in 1996 . Outsourcing to China appears to be an important contributing factor to this employment shift. Using a regression similar to (15), Hsieh and Woo find a strong positive correlation between the nonproduction wage share and imports from China (expressed as the ratio of industry imports from China to either industry absorption or total materials purchases) for Hong Kong industries. Over the period 1976-1996, outsourcing to China can account for 45 $60 \%$ of the increase in the nonproduction wage share in Hong Kong manufacturing.

Outsourcing may also raise the relative demand for skilled labor in the country to which production is transferred. In Feenstra and Hanson (1996), firms in the skill-abundant North use firms in the nonskill-abundant South to produce intermediate inputs. Assuming wages differ between nations, the North specializes in high-skill tasks and the South specializes in low-skill tasks. If Northern firms outsource production to the South, they will choose to move the least skill-intensive activities that they perform. By moving these activities to the South, the average skill intensity of production rises in the North. The same also happens in the South, since the South initially specializes in the most low-skill tasks. Thus, outsourcing from the North to the South raises the relative demand and so the relative earnings of high-skilled workers in both countries, contributing to a global increase in wage inequality.

countries they tend to replicate production activities done at home, which may lower employment in Japan but does not change skill intensity. 
During the 1980's Mexico, liberalized foreign investment and trade and experienced an increase in the relative wage of skilled labor (Hanson and Harrison, 1999). In the period following reform, FDI in Mexico was concentrated in foreign assembly plants, known as maquiladoras, most of which are located in Mexican states along the U.S. border. These assembly plants are created, in most cases, by U.S. firms outsourcing unskilled-labor intensive production activities to Mexico. Feenstra and Hanson (1997) find that for the period 1975-1988 the shift in Mexican manufacturing towards foreign assembly plants can account for $45 \%$ of the observed increase in the country's nonproduction wage share. ${ }^{22}$

Outsourcing changes the relative wage by inducing an outward shift in the relative demand for skilled labor. An alternative view is that international trade changes factor prices by flattening labor demand curves, making them more elastic. Leamer (1998) presents an extreme version of this story, in which the transition of an economy from autarky to trade transforms an economy's labor demand curve from being downward sloping to being horizontal, at least over sections that correspond to diversified production. Extending this logic, Rodrik (1997) identifies several mechanism through which greater economic integration between countries may make labor demand curves flatter. In one of the few attempts to test this hypothesis, Slaughter (2001) estimates the own-price elasticity of labor demand for production and nonproduction workers in two-digit U.S. manufacturing industries over the period 1960-1991. Over the entire sample, demand became more elastic for production labor, but not for nonproduction labor. The sectors

22 Their estimation equation is based on Feenstra and Hanson (1996), and differs somewhat from that in (15). In this specification, the level of foreign assembly activities is treated as an endogenous variable. 
with the largest increase in elasticities were food and tobacco, apparel and textiles, wood and paper, and primary and fabricated metals, which include some of the least-skill intensive manufacturing industries. The demand for production labor became more elastic in industries with more outsourcing, more investment in computers, and more investment in high-tech capital overall. These results are robust to controls for industry fixed effects but not time fixed effects, suggesting that changes in labor-demand elasticities are dominated by a trend component.

\subsection{Estimation of Zero-Profit Conditions}

In the second empirical method, we drop the short-run framework that was used above, and instead suppose that capital can be adjusted along with skilled and unskilled labor. The industry cost function is then written as in (6), which is re-expressed as:

$$
\mathrm{C}_{\mathrm{m}}\left(\mathrm{w}_{\mathrm{m}}, \mathrm{q}_{\mathrm{m}}, \mathrm{r}_{\mathrm{m}}, \mathrm{Y}_{\mathrm{m}}, \mathrm{p} / \mathrm{p}_{\mathrm{m}}\right) \equiv \min _{\mathrm{L}_{\mathrm{m}}, \mathrm{H}_{\mathrm{m}} \mathrm{K}_{\mathrm{m}}} \mathrm{w}_{\mathrm{m}} \mathrm{L}_{\mathrm{m}}+\mathrm{q}_{\mathrm{m}} \mathrm{H}_{\mathrm{m}}+\mathrm{r}_{\mathrm{m}} \mathrm{K}_{\mathrm{m}} \text {, subject to (4). }
$$

Notice that in (16) we have allowed the factor prices $\mathrm{w}_{\mathrm{m}}, \mathrm{q}_{\mathrm{m}}$, and $\mathrm{r}_{\mathrm{m}}$ to differ across the industries $\mathrm{m}=1, \ldots, \mathrm{M}$. This reflects the empirical fact that factor prices, and wages in particular, do differ across industries (Krueger and Summers, 1988); this will turn out to be important in what follows. As before, the relative price of imported inputs enters this cost function because it also appears in the production function (4); we will replace this by the vector $\mathrm{z}_{\mathrm{m}}$, which includes

other structural variables. Since the production function (4) is linearly homogeneous in inputs, then we can rewrite the cost function in (16) as,

$$
C_{m}\left(w_{m}, q_{m}, r_{m}, Y_{m}, z_{m}\right)=Y_{m} c_{m}\left(w_{m}, q_{m}, r_{m}, z_{m}\right)
$$

where $\mathrm{c}_{\mathrm{m}}\left(\mathrm{w}_{\mathrm{m}}, \mathrm{q}_{\mathrm{m}}, \mathrm{r}_{\mathrm{m}}, \mathrm{z}_{\mathrm{m}}\right)$ denotes the unit-cost function. 
The zero-profit conditions in the industries are therefore expressed as,

$$
\mathrm{p}_{\mathrm{m}}=\mathrm{c}_{\mathrm{m}}\left(\mathrm{w}_{\mathrm{m}}, \mathrm{q}_{\mathrm{m}}, \mathrm{r}_{\mathrm{m}}, \mathrm{z}_{\mathrm{m}}\right), \quad \mathrm{m}=1, \ldots, \mathrm{M}
$$

In our theoretical model of section 3, we examined how changes in product prices would affect factor prices. Now, however, the presence of the structural variables $\mathrm{z}_{\mathrm{m}}$ mean that the changes in prices reflect more than just changes in factor prices. Indeed, taking the difference between these, we can define total factor productivity in the industry as,

$$
\operatorname{TFP}_{\mathrm{m}} \equiv\left(\theta_{\mathrm{mL}} \hat{\mathrm{w}}_{\mathrm{m}}+\theta_{\mathrm{mH}} \hat{\mathrm{q}}_{\mathrm{m}}+\theta_{\mathrm{mK}} \hat{\mathrm{r}}_{\mathrm{m}}\right)-\hat{\mathrm{p}}_{\mathrm{m}}
$$

where the cost-shares of the three factors sum to unity, $\theta_{\mathrm{mL}}+\theta_{\mathrm{mH}}+\theta_{\mathrm{mK}}=1$. Productivity improvements mean that factor prices can rise more than product prices (or conversely, that product prices can fall further). Note that (18) is the "dual" definition of productivity, and empirically it is very close to the "primal" definition, which is the growth in output minus a weighted average of the growth in inputs. In either case, we should think of changes in the structural variables $\mathrm{z}_{\mathrm{m}}$ as the underlying cause of changes in productivity. ${ }^{23}$

Shuffling the terms in (18) slightly, and replacing the instantaneous change in prices with discrete changes like $\Delta \ln \mathrm{p}_{\mathrm{m}}$, we obtain the equation,

23 We convert (18) to a discrete-time formula by replacing the instantaneous changes by the change in log prices between two years. In that case, we need to be specific about the year in which the factor shares are measured. A preferred method is to use the arithmetic average of the factor cost-shares in the two years, and this formulation is called the Tornqvist index of productivity. Caves, Christensen and Diewert (1982a,b) show that the Tornqvist index is a valid measure of Hicks-neutral or factor-biased productivity change - i.e., it is valid even when the shift parameters in the translog production or cost function have a non-neutral impact on factor demands. 


$$
\Delta \ln \mathrm{p}_{\mathrm{m}}=-\mathrm{TFP}_{\mathrm{m}}+\theta_{\mathrm{mL}} \Delta \ln \mathrm{w}_{\mathrm{m}}+\theta_{\mathrm{mH}} \Delta \ln \mathrm{q}_{\mathrm{m}}+\theta_{\mathrm{mK}} \Delta \ln \mathrm{r}_{\mathrm{m}}, \quad \mathrm{m}=1, \ldots, \mathrm{M}
$$

We consider estimating (19) as a linear regression across industries, where the data are the change in log prices, productivity, and the factor cost-shares, while the change in factor-prices are estimated as regression coefficients. That is, we estimate the implied change in factor-prices $\omega_{\mathrm{L}}, \omega_{\mathrm{H}}$, and $\omega_{\mathrm{K}}$ from the regression:

$$
\Delta \ln \mathrm{p}_{\mathrm{m}}=-\mathrm{TFP}_{\mathrm{m}}+\theta_{\mathrm{mL}} \omega_{\mathrm{L}}+\theta_{\mathrm{mH}} \omega_{\mathrm{H}}+\theta_{\mathrm{mK}} \omega_{\mathrm{K}}+\varepsilon_{\mathrm{m}}, \quad \mathrm{m}=1, \ldots, \mathrm{M}
$$

where $\varepsilon_{\mathrm{m}}$ is an error term, specified more fully below. We interpret the coefficients $\omega_{\mathrm{L}}, \omega_{\mathrm{H}}$, and $\omega_{\mathrm{K}}$ as the change in factor prices that are mandated by the change in product prices, which is the dependent variable in (19). Baldwin and Hilton (1984) were among the first to estimate a price regression like (20). Recent applications include Sachs and Shatz (1994), Baldwin and Cain (1997), Krueger (1997), Leamer (1998), Feenstra and Hanson (1999), and Slaughter (2000b).

Estimates of (20) for 447 U.S. manufacturing industries, over 1979-1990, are provided in Table 5. The dependent variable is the log change in the industry output price over the period, divided by the number of sample years to obtain an annualized difference. We use the primal measure of TFP, expressed as an annualized difference. The other independent variables are the average cost-shares (over the first and last year for the period) for production labor, nonproduction labor, and capital; the materials cost share times the log change in materials prices; and the energy cost share times the log change in energy prices.

In columns (1) and (2), we constrain the coefficients on the materials share times the materials price and the energy share times the energy price to be unity, which transforms the dependent variable to be the log change in value-added prices. This approximates the 
specification in Leamer (1998). In column (1), the coefficients on the labor shares imply a decrease in the nonproduction-production wage gap, since the nonproduction-production relative wages is mandated to change by $2.30 \%-3.06 \%=-0.76 \%$ per year, which is consistent with the results in Leamer (1998). In fact, the nonproduction-production wage gap rose by $0.74 \%$ per year (actual annual average changes in factor prices are shown in column (5) of Table 5). In column (2), we follow Sachs and Shatz (1994) and drop the office-equipment industry (SIC 3573), which reverses the predicted change in wage inequality. Now, nonproduction wages are mandated to rise by $1.5 \%$ per year more than production wages. In column (3), we approximate Krueger's (1997) specification by dropping TFP as a regressor, while estimating coefficients on materials and energy. There is again a mandated rise in the nonproduction-production wage gap, but one that is much larger than the actual increase in relative wages.

The estimates in Table 5 are troubling because they show that slight changes in the data, such as dropping the office-equipment industry, have a dramatic effects on the results. While it is true that office equipment is an outlier, the sensitivity of the results to the specification suggests that something more basic is going on. To address this, let us ask: why do the estimates of $\omega_{\mathrm{L}}, \omega_{\mathrm{H}}$, and $\omega_{\mathrm{K}}$ from (20) differ at all from the actual average change in manufacturing wages (shown in column (5)), which we denote by $\overline{\Delta \ln \mathrm{w}}, \overline{\Delta \ln \mathrm{q}}$, and $\overline{\Delta \ln \mathrm{r}}$ ? The overbar indicates that we are averaging the change in factor-prices over all manufacturing industries. By just comparing (19) and (20), it seems that there should be some close connection between the estimates $\omega_{\mathrm{L}}, \omega_{\mathrm{H}}$, and $\omega_{\mathrm{K}}$ and these average actual factor price changes, but we need to uncover what this connection is.

To achieve this, let us make the transition from (19) to an estimating equation more carefully. First, notice that we can rewrite (19) as, 


$$
\Delta \ln \mathrm{p}_{\mathrm{m}}=-\mathrm{TFP}_{\mathrm{m}}+\theta_{\mathrm{mL}} \overline{\Delta \ln \mathrm{w}}+\theta_{\mathrm{mH}} \overline{\Delta \ln \mathrm{q}}+\theta_{\mathrm{mK}} \overline{\Delta \ln \mathrm{r}}+\varepsilon_{\mathrm{m}}
$$

where,

$$
\varepsilon_{\mathrm{m}} \equiv \theta_{\mathrm{mL}}\left(\overline{\Delta \ln \mathrm{w}}-\Delta \ln \mathrm{w}_{\mathrm{m}}\right)+\theta_{\mathrm{mH}}\left(\overline{\Delta \ln \mathrm{q}}-\Delta \ln \mathrm{q}_{\mathrm{m}}\right)+\theta_{\mathrm{mK}}\left(\overline{\Delta \ln \mathrm{r}}-\Delta \ln \mathrm{r}_{\mathrm{m}}\right)
$$

Thus, we replace the industry wage changes on the right of (19) by the average wage changes, and incorporate the difference between these two into an error term. In economic terms, $\varepsilon_{\mathrm{m}}$ reflects interindustry wage differentials - i.e., the difference between wages paid in each industry and the manufacturing average. It is well known that these wage differentials vary systematically across industries (with capital-intensive industries paying higher wages), and are fairly stable over time (Krueger and Summers, 1988).

We can estimate (19') as the regression (20), where now we have been careful to derive the error term $\varepsilon_{\mathrm{m}}$. But this derivation is enough to answer the question we posed above: the estimates of $\omega_{\mathrm{L}}, \omega_{\mathrm{H}}$, and $\omega_{\mathrm{K}}$ obtained from (20) will be unbiased estimates of the average actual factor price-changes in (19') if and only if the error term $\varepsilon_{\mathrm{m}}$ in (20') is uncorrelated with the cost-shares $\theta_{\mathrm{mL}}, \theta_{\mathrm{mH}}, \theta_{\mathrm{mK}}$. This result follows directly from the properties of ordinary leastsquares, whereby the independent variables need to be uncorrelated with the error term to obtain unbiased estimates. But this property is unlikely to be true in our data. Industries such as office equipment have both a high share of nonproduction labor (e.g., engineers), and probably the fastest growing industry wage differential, as these workers have had very rapid wage gains. This means that the error term $\varepsilon_{\mathrm{m}}$ is negative for office equipment, resulting in a negative correlation with the cost-share of nonproduction labor. Indeed, this negative correlation may explain why the estimated change in nonproduction wages is lower in column (1) than in column 
(2) of Table 5 (and why both estimates are lower than the actual change in nonproduction wages in column (5)).

To correct this problem, we can simply include the error term $\varepsilon_{\mathrm{m}}$ as an additional regressor in the equation, reflecting the change in interindustry wage differentials. It is convenient to combine $\varepsilon_{\mathrm{m}}$ with $\mathrm{TFP}_{\mathrm{m}}$, obtaining a measure of "effective" TFP:

$$
\begin{aligned}
\operatorname{ETFP}_{\mathrm{m}} & \equiv \mathrm{TFP}_{\mathrm{m}}-\varepsilon_{\mathrm{m}} \\
& =\left(\theta_{\mathrm{mL}} \overline{\Delta \ln \mathrm{w}}+\theta_{\mathrm{mH}} \overline{\Delta \ln \mathrm{q}}+\theta_{\mathrm{mK}} \overline{\Delta \ln \mathrm{r}}\right)-\Delta \ln \mathrm{p}_{\mathrm{m}}
\end{aligned}
$$

Thus, this measure of effective productivity shows how the average manufacturing factor-price changes, weighted using the cost-share in each industry, differ from the change in product price of that industry. Making use of (21), the regression in (20) is written once again as,

$$
\Delta \ln \mathrm{p}_{\mathrm{m}}=-\mathrm{ETFP}_{\mathrm{m}}+\theta_{\mathrm{mL}} \omega_{\mathrm{L}}+\theta_{\mathrm{mH}} \omega_{\mathrm{H}}+\theta_{\mathrm{mK}} \omega_{\mathrm{K}}, \quad \mathrm{m}=1, \ldots, \mathrm{M}
$$

Now, there is no error term at all in this regression, so it ought to provide a perfect fit when estimated. This will not be true exactly in our data, since we are using the primal rather than the dual measure of TFP to construct effective TFP in (21). These priors are confirmed in columns (4) and (5) of Table 5. In column (4), the dependent variable is the log change in value-added prices; in column (5), it is the log change in output prices, since we allow the coefficients on the materials and energy shares to differ from unity. In either specification, the coefficients on the labor and capital shares are extremely close to the actual average annual percentage changes in factor prices, which are 4.71 for production labor, 5.44 for nonproduction labor, and 3.95 for capital. Thus, when we properly estimate (20), we end up with an identity! 
Summarizing our results so far, we started with the goal of estimating the zero-profit conditions, to obtain "mandated" changes in factor prices that are consistent with the change in product prices. A number of researchers have estimated an equation like (20), without much attention to the error term in this regression. When we carefully derive the error term, as in $\left(20^{\prime}\right)$, we then realize that it may well be correlated with the factor cost-shares, which are the independent variables. To correct for this we can include the error term as data, by incorporating it into "effective" total factor productivity, as in (22). But now we encounter another problem: this gives essentially a perfect fit, just reproducing the actual change in factor prices. That means the regression does not provide us with any new information at all! This is a discouraging finding, and calls into question the whole approach.

To make further progress, Feenstra and Hanson (1999) propose a two-step estimation procedure. In the first step, we combine the variables $\Delta \ln \mathrm{p}_{\mathrm{m}}+\operatorname{ETFP}_{\mathrm{m}}$ that appear in (22), and regress these on the structural variables $\mathrm{z}_{\mathrm{m}}$. Supposing that there are only two structural variables, $\mathrm{z}_{1 \mathrm{~m}}$ and $\mathrm{z}_{2 \mathrm{~m}}$, we therefore run the regression:

$$
\Delta \ln \mathrm{p}_{\mathrm{m}}+\mathrm{ETFP}_{\mathrm{m}}=\eta_{0}+\eta_{1} \Delta \mathrm{z}_{1 \mathrm{~m}}+\eta_{2} \Delta \mathrm{z}_{2 \mathrm{~m}}, \mathrm{~m}=1, \ldots, \mathrm{M}
$$

We then take the estimated coefficients $\hat{\eta}_{1}$ and $\hat{\eta}_{2}$, and use these to construct the dependent variables for the second-step regressions,

$$
\begin{aligned}
& \hat{\eta}_{1} \Delta z_{1 \mathrm{~m}}=\theta_{\mathrm{mL}} \omega_{1 \mathrm{~L}}+\theta_{\mathrm{mH}} \omega_{1 \mathrm{H}}+\theta_{\mathrm{mK}} \omega_{1 \mathrm{~K}}, \\
& \hat{\eta}_{2} \Delta \mathrm{z}_{2 \mathrm{~m}}=\theta_{\mathrm{mL}} \omega_{2 \mathrm{~L}}+\theta_{\mathrm{mH}} \omega_{2 \mathrm{H}}+\theta_{\mathrm{mK}} \omega_{2 \mathrm{~K}}, \quad \mathrm{~m}=1, \ldots, \mathrm{M} .
\end{aligned}
$$

That is, we use the estimated coefficients $\hat{\eta}_{1}$ and $\hat{\eta}_{2}$ times each structural variable as the dependent variables in (24), and regress these on the factor cost-shares. The coefficients 
obtained from the second-stage regression, $\omega_{1 \mathrm{~L}}, \omega_{1 \mathrm{H}}, \omega_{1 \mathrm{~K}}$ and $\omega_{2 \mathrm{~L}}, \omega_{2 \mathrm{H}}, \omega_{2 \mathrm{~K}}$, are interpreted as the portion of the total change in factor-prices that are explained by that structural variable. In this way, we are taking the total change in factor-prices, and decomposing it into parts that are explained by each structural variable.

In the estimation of (23) for U.S. manufacturing industries over the period 1979-1990, Feenstra and Hanson (1999) find positive and statistically significant correlations between TFPadjusted value-added prices and foreign outsourcing, the computer share of the capital stock, and the computer share of investment (but not with the high-tech capital share). This is consistent with these structural variables having positive effects on productivity, as expected, and on valueadded prices. ${ }^{24}$ The latter effect arises from the non-neutral impact that the structural variables have on industry productivity - outsourcing and capital upgrading both induce shifts away from production labor and towards nonproduction labor - which then leads to changes in relative product prices (in particular, raising value-added prices for skill-intensive goods). Over the period $1979-1990$, the structural variables account for $11 \%$ to $23 \%$ of the variation in TFPadjusted value-added prices in U.S. manufacturing.

The second stage of this technique is to decompose the change in TFP-adjusted valueadded prices into portions attributable to each structural variable and then, following (24), regress these decomposed product-price changes on the factor-cost shares to obtain mandated changes in factor prices. The results suggest that both outsourcing and capital upgrading

\footnotetext{
${ }^{24}$ Feenstra and Hanson (1999) verify that the structural variables affect both TFP and value-added prices directly. Were the structural variables to affect just TFP, they would affect value-added prices indirectly, through the passthrough of productivity changes to product-price changes. Feenstra and Hanson find that the structural variables affect value-added prices over and above their impact on productivity.
} 
contributed to rising wage inequality in the 1980's. Over the 1979-1990 period, outsourcing accounts for $15 \%$ of the increase in the relative wage of nonproduction workers, and computers measured using ex post rental prices account for $35 \%$ of this increase; thus, computers are twice as important as outsourcing. When instead the computer share of the capital stock is measured using ex ante rental prices, then outsourcing explains about $25 \%$ while computers explain about $20 \%$ of the increase in the nonproduction/production wage. Finally, when the computer share of the capital stock is replaced with the computer share of investment, then the contribution of outsourcing falls to about $10 \%$, while the contribution of computers rises so much that it explains the entire increase in the relative wage. Thus, as in Table 4 where we examined the change in the nonproduction labor share, when we now consider the factors influencing the relative wage, we find that both outsourcing and computer expenditure are important with their exact magnitudes depending on how these variables are measured.

Economic integration between countries may, of course, also contribute directly to changes in factor prices, as lower tariffs or transportation costs lead to changes in product prices which would then affect factor prices in standard Stolper-Samuelson (1941) fashion. In principle, one could uncover the impact of changing tariffs and transportation costs on product prices and productivity, following (23), and use these results to estimate their impact on factor prices, following (24). Haskel and Slaughter (2000) show that in the 1970's U.S. manufacturing industries with higher tariffs and higher transportation costs tended to have lower relative employment of nonproduction workers, and that over the period 1974-1988 reductions in tariffs and transportation costs were larger in less-skill-intensive industries. This is suggestive evidence that falling trade costs may have contributed to rising wage inequality. But other evidence is missing: changes in tariffs and transportation costs do poorly in explaining changes in product 
prices across U.S. industries over the 1974-1988 period. Robertson (2000) finds stronger results for Mexico: over 1987-1993, when Mexico's skilled-unskilled wage gap rose, tariffs fell more in less-skill-intensive industries, and over 1993-1998, when Mexico's skilled-unskilled wage gap fell, tariffs fell more in skill-intensive sectors.

The United Kingdom is another country that has experienced rising wage inequality of the same magnitude as the United States. Haskel and Slaughter (2001) apply the two-stage estimation procedure of Feenstra and Hanson (1999) to data on U.K. manufacturing industries over the period 1960-1990, using as structural variables union density (the share of union workers in industry employment), industry concentration (share of sales by the five largest firms), innovations per industry, import prices, and computerization (share of firms in the industry using computers). They find that TFP growth is higher in industries with more innovations, lower initial union density, lower initial sales concentration, and larger reductions in import prices (but is unrelated with computerization). Product price changes are lower in industries with smaller changes in import prices. During the 1980's, when U.K. wage inequality rose, the structural variable that appears to have contributed most to the increase in the skilledunskilled wage gap is industry innovation. The contribution of import prices is comparatively small. This contrasts with research (Anderton and Brenton, 1997) showing that rising imports over 1970-83 is a significant determinant of the nonproduction labor share in the U.K.

\subsection{Estimation of Economy-wide GDP Function}

The third empirical method we shall discuss takes the longest-run view of the economy, in which capital and all other factors fully adjust to their equilibrium levels across industries. Rather than focusing on each industry, we now look at the economy overall, and consider how 
gross domestic product (GDP) is produced from the total factor endowments, given the prices of domestic and traded goods. Letting $\left(\mathrm{L}_{\mathrm{m}}, \mathrm{H}_{\mathrm{m}}, \mathrm{K}_{\mathrm{m}}\right)$ denote the factor demands within each industry $m=1, \ldots, M$, the sum of these cannot exceed the endowments $(L, H, K)$ :

$$
\sum_{\mathrm{m}=1}^{\mathrm{M}} \mathrm{L}_{\mathrm{m}} \leq \mathrm{L}, \quad \sum_{\mathrm{m}=1}^{\mathrm{M}} \mathrm{H}_{\mathrm{m}} \leq \mathrm{H}, \quad \text { and } \quad \sum_{\mathrm{m}=1}^{\mathrm{M}} \mathrm{K}_{\mathrm{m}} \leq \mathrm{K} .
$$

Using the production functions in (3) for each industry, the GDP function for the economy is defined as:

$$
\mathrm{G}(\mathrm{L}, \mathrm{H}, \mathrm{K}, \mathrm{P}) \equiv \max _{\mathrm{L}_{\mathrm{m}}, \mathrm{H}_{\mathrm{m}} \mathrm{K}_{\mathrm{m}}}^{\operatorname{m}} \sum_{\mathrm{m}=1}^{\mathrm{M}} \mathrm{F}_{\mathrm{m}}\left(\mathrm{L}_{\mathrm{m}}, \mathrm{H}_{\mathrm{m}}, \mathrm{K}_{\mathrm{m}}, \mathrm{p}_{\mathrm{m}}, \mathrm{p}\right) \text {, subject to (25), }
$$

where $\mathrm{P}=\left(\mathrm{p}_{1}, \ldots, \mathrm{p}_{\mathrm{M}}, \mathrm{p}\right)$ denotes the vector of all product prices $\mathrm{p}_{\mathrm{m}}$ as well the prices $\mathrm{p}$ of all imported intermediate imports. Let us say there are $\mathrm{N}>\mathrm{M}$ prices in total, so that $\mathrm{P}=\left(\mathrm{p}_{1}, \ldots, \mathrm{p}_{\mathrm{N}}\right)$. Within the list of $\mathrm{M}$ industries, we are including both manufacturing and services, whether these products are traded or not.

In order to estimate (26) we need to choose a functional form, and as in our discussion of the cost function, a convenient choice is the translog function. This is written in a general notation as,

$$
\begin{array}{r}
\ln \mathrm{G}=\alpha_{0}+\sum_{\mathrm{m}=1}^{\mathrm{N}} \alpha_{\mathrm{m}} \ln \mathrm{p}_{\mathrm{m}}+\sum_{\mathrm{k}=1}^{\mathrm{K}} \beta_{\mathrm{k}} \ln \mathrm{v}_{\mathrm{k}}+\frac{1}{2} \sum_{\mathrm{m}=1}^{\mathrm{N}} \sum_{\mathrm{n}=1}^{\mathrm{N}} \gamma_{\mathrm{mn}} \ln \mathrm{p}_{\mathrm{m}} \ln \mathrm{p}_{\mathrm{n}} \\
+\frac{1}{2} \sum_{\mathrm{k}=1}^{\mathrm{K}} \sum_{\ell=1}^{\mathrm{K}} \delta_{\mathrm{k} \ell} \ln \mathrm{v}_{\mathrm{k}} \ln \mathrm{v}_{\ell}+\sum_{\mathrm{m}=1}^{\mathrm{N}} \sum_{\mathrm{k}=1}^{\mathrm{K}} \phi_{\mathrm{mk}} \ln \mathrm{p}_{\mathrm{m}} \ln \mathrm{v}_{\mathrm{k}}
\end{array}
$$

where $\mathrm{p}_{\mathrm{m}}$ denotes the prices of the outputs and imported inputs, $\mathrm{m}=1, \ldots, \mathrm{N}$, while $\mathrm{v}_{\mathrm{k}}$ denotes the endowments of the factors of production, $\mathrm{k}=1, \ldots, \mathrm{K}$. For the GDP function in (26), there are just 
three endowments - skilled and unskilled labor, and capital. In order to ensure that the GDP function is linearly homogeneous in prices, we impose the requirements, ${ }^{25}$

$$
\sum_{n=1}^{N} \alpha_{n}=1 \text { and } \sum_{m=1}^{N} \gamma_{m n}=\sum_{n=1}^{N} \gamma_{m n}=0
$$

As usual, we can differentiate the GDP function with respect to factor endowments to obtain factor prices, $\partial \mathrm{G} / \partial \mathrm{v}_{\mathrm{k}}=\mathrm{w}_{\mathrm{k}}$. It follows that the derivative of the log of GDP with respect to the $\log$ of endowments, $\partial \ln G / \partial \ln v_{k}=w_{k} v_{k} / G$, equals the share of GDP paid to each factor, which we denote by $s_{k}, k=1, \ldots, K$. Computing this for the GDP function in (27), we obtain:

$$
\mathrm{s}_{\mathrm{k}}=\beta_{\mathrm{k}}+\sum_{\ell=1}^{\mathrm{K}} \delta_{\mathrm{k} \ell} \ln \mathrm{v}_{\ell}+\sum_{\mathrm{m}=1}^{\mathrm{N}} \phi_{\mathrm{mk}} \ln \mathrm{p}_{\mathrm{m}}, \quad \mathrm{k}=1, \ldots, \mathrm{K} .
$$

In addition, differentiating the GDP function with respect to a product price yields output of that good (inclusive of exports), and differentiating with respect to an import price yields the negative of imports. Therefore, the derivative of the log of GDP with respect to the log of a price equals the share of GDP obtained from that output, which we denote by $s_{n}, n=1, \ldots, N$. Note that for imported inputs, these shares are negative. Computing these from (27):

$$
\mathrm{s}_{\mathrm{m}}=\alpha_{\mathrm{m}}+\sum_{\mathrm{n}=1}^{\mathrm{N}} \gamma_{\mathrm{mn}} \ln \mathrm{p}_{\mathrm{n}}+\sum_{\mathrm{k}=1}^{\mathrm{K}} \phi_{\mathrm{mk}} \ln \mathrm{v}_{\mathrm{k}}, \quad \mathrm{m}=1, \ldots, \mathrm{N}
$$

\footnotetext{
25 Without loss of generality, we also impose the symmetry restrictions $\gamma_{\mathrm{mn}}=\gamma_{\mathrm{nm}}$ and $\delta_{\mathrm{mk}}=\delta_{\mathrm{km}}$.
} 
Thus, given annual data on product prices and quantities, along with factor prices and endowments, we can estimate (29) and (30) as a system of linear equations. This will allow us to determine the effect of product prices on factor shares - measured by $\phi_{\mathrm{mk}}$. Notice that these coefficients enter both the factor-share equations in (29), and the product-share equations in (30), so that estimating these simultaneously allows us to test the restriction that $\phi_{\mathrm{mk}}$ estimated from (29) and (30) are equal. If this hypothesis is accepted, then the restriction can be imposed, and this allows the estimates of $\phi_{\mathrm{mk}}$ to become more precise. An advantage of this system approach is that the number of years (say T) is multiplied by the number of equations, $(\mathrm{N}-1)$ for products plus (K-1) for factors, to obtain the total number of observations $\mathrm{T}(\mathrm{N}+\mathrm{K}-2) .{ }^{26}$ Thus, even though the number of parameters being estimated is large, we can obtain reasonable estimates even if we only have annual data for one or two decades.

Estimates of the GDP function have been made by a number of authors for various countries, including the United States. The reader is referred to Kohli (1991) for the most comprehensive treatment. For the purposes of this survey, we are interested in applications that distinguish skilled versus unskilled labor. Tombazos (1999) attempts to make this distinction by identifying industries that are intensive in skilled or unskilled labor, and then forming aggregate wages and employment indexes over each group of industries; these indexes are then used as a proxy for the price and quantity of skilled and unskilled labor. Imports are treated as an input into the production process, just as they are in the GDP function (26). Tombazos incorporates skilled labor, unskilled labor, capital and imports into the estimation of an aggregate cost function for the U.S., over 1967-1994, with a single aggregate output (including exports). His

\footnotetext{
26 Because the shares sum to unity, one product-share and one factor-share equation must be dropped.
} 
major conclusion is that a drop in the import price reduces the demand for unskilled labor, but raises the demand for skilled labor in the U.S. This is highly consistent our theoretical model of section 3. According to Tombazos, an effect like this holds for the U.S. economy in the aggregate. Missing from his analysis, though, is a discussion of how much import prices have fallen, and therefore, how much of the shift towards skilled labor can be explained by this channel of influence.

This shortcoming does not appear in the work of Harrigan and Balaban (1999) and Harrigan (2000). Harrigan and Balaban estimate the system of equations in (29) and (30) for the United States over the period 1963-1991 using data on four factors (high-school dropouts, highschool graduates, college graduates, capital), and four sectors (skill-intensive traded goods, unskilled-intensive traded goods, skill-intensive nontraded goods, and unskilled-intensive nontraded goods). Thus, imports are not explicitly identified. In contrast, Harrigan (2000) has two categories of outputs (skill-intensive and unskilled-intensive final output), and seven factors including imports (oil imports, two other groups of imports, and the three types of labor and capital). It turns out that changes in the import prices have been quite small in comparison with other prices changes, especially in nontraded goods, so that changes in import prices are not an important explanation for changes in wages. We therefore focus below on the results of Harrigan and Balaban, which except for imports, are similar to those of Harrigan.

With the estimated coefficients from the share equations (29) and (30) in hand, Harrigan and Balaban calculate wage elasticities with respect to factor quantities and product prices. As expected, the own-quantity elasticity of each factor price is negative. Increasing the supply of capital raise wages for all workers, but these elasticities are increasing in education levels, such that a $10 \%$ increase in the capital stock would increase the college/high-school graduate relative 
wage by about $3.5 \%$, and the college/high-school dropout relative wage by about $8 \%$. The wage elasticities of traded goods prices are imprecisely estimated, while those for nontraded goods are somewhat surprising. Increases in prices of skill-intensive nontraded goods raises wages for college graduates and high-school dropouts, but lowers wages for high-school graduates, and increases in prices of unskilled-intensive nontraded goods has a large positive effect on highschool-graduate wages, a moderate positive effect on college wages, and a negative effect on high-school-dropout wages.

Putting the estimated wage elasticities together with observed changes in factor supplies and product prices, we can decompose the contribution of different variables to the observed change in factor prices. While capital accumulation contributed to an increase in the relative wage of college graduates, this effect was largely offset by increases in the supply of college graduates. The big changes during the latter part of the sample period were an increase in the relative price of skill-intensive nontraded goods, such as finance, insurance and real estate. This had the largest impact on raising the college/high-school-graduate relative wage. Conversely, there was a decrease in the relative price of unskilled-intensive nontraded goods, such as wholesale and retail trade, which had the largest impact on reducing the relative wage of highschool dropouts. In short, the increase in the relative wage of skilled labor, in the 1980s and beyond, is highly correlated with the rise in the price of nontraded goods that use skilled labor, and similarly for unskilled labor where both the relative wage and price fell.

These correlations beg the questions of whether the change in nontraded prices caused the change in wages, or conversely. We provided a theoretical example in section 3.3 of a case where capital leaves the country, increasing the relative wage of skilled labor, and therefore raising the price of skill-intensive nontradables and lowering the price of unskilled-intensive 
nontradables. This story would be consistent with the estimates of Harrigan and Balaban. We cannot rule out, however, the idea that the nontradables prices are changing due to some other reason (e.g. rising incomes and demand leading to an increase in the price of skill-intensive nontradables), which is therefore the proximate cause of the change in wages. As Harrigan (2000, p. 186) puts it: “To my knowledge, there are no scholarly studies of relative price determination in the United States that might shed light on the causes of the changes shown... and until we understand the cause of these price changes we cannot rule out an important role for import competition."

\section{Conclusions}

There is an emerging view in the literature on wage inequality in the United States and other advanced countries that technological change matters for changes in the wage structure but international trade does not (Katz and Autor, 1999). The research we survey in this chapter fails to support this conclusion. While there is abundant evidence of skill-biased technological change, it also appears that international trade, in the form of foreign outsourcing, contributes to skill upgrading and increases in the skilled-unskilled wage gap.

The argument against trade is based, in part, on a misreading of the data. Stable trade to GDP ratios, an apparent increase in the relative price of skill-intensive goods, and employment shifts towards skilled workers that occur mainly within, rather than between, industries are all cited as evidence that trade cannot have contributed to rising wage inequality. This line of reasoning emphasizes trade in final goods and ignores the globalization of production and recent dramatic increases in trade in intermediate inputs. Much recent growth in trade has resulted from firms breaking industries apart by locating low-skill activities in low-wage countries and high-skill activities in high-wage countries. When trade takes this form, its impact on relative 
prices and factor allocation can be much different than that predicted by standard models of trade in final goods. Recent literature shows that trade to merchandise GDP ratios have risen sharply in recent years, with much of the growth in trade attributable to intermediate inputs, that changes in the relative prices of domestic versus imported goods are consistent with trade shifting out the relative demand for skilled labor, and that trade in intermediate inputs is consistent with skill upgrading being a within-industry phenomenon.

Beyond the prima facie case that trade raises wage inequality, there is evidence of a direct link. Using data on changes in industry behavior over time, we see that foreign outsourcing is associated with increases in the share of wages paid to skilled workers in the United States, Japan, Hong Kong, and Mexico. In several of these cases, outsourcing can account for half or move of the observed skill upgrading. For the United States, there is evidence that during the 1980's and 1990's outsourcing contributed to changes in industry productivity and product prices that in turn mandated increases in the relative wage of skilled labor.

Existing literature has just begun to scratch the surface of how the globalization of production changes industry structure and factor demand in advanced and emerging economies. There is as of yet little research on foreign outsourcing in Eastern Europe, Southeast Asia (Cheng and Kierzkowski, 2001), or Central America and the Caribbean (Feenstra, Hanson and Swenson, 2000), though anecdotal evidence suggests that it is an important mechanism through which countries in these regions integrate themselves into the world economy. There are clearly rich opportunities for research in this area.

Global production sharing and trade in intermediate inputs matter more generally for how we apply trade models to data. In tests of the Heckscher-Ohlin model, it is standard to assume 
that exports are produced entirely by combining domestic factors of production with domestically-produced intermediate inputs. We now know that this assumption is wrong. Antweiler and Trefler (2000), Davis and Weinstein (2000) and Trefler and Zhu (2000) show that trade in intermediate inputs can help resolve the mystery of the missing trade (Trefler, 1995), in which the estimated factor content of trade is near zero, and that existing tests of trade theory may produce severely biased estimates of the factor content of trade if they fail to account for global production. While we can easily address this problem by adopting more general trade models in which trade occurs in both final and intermediate goods, the literature has yet to take this necessary step. 


\section{References}

Anderton, Bob and Paul Brenton (1997) "Outsourcing and Low-Skilled Workers in the UK," National Institute of Economic and Social Research, London, mimeo.

Antweiler, W. and D. Trefler. (2000) "Increasing Returns and All That: A View from Trade," NBER Working Paper No. 7941.

Arndt, Sven. (1998a) "Globalization and the Gains from Trade," in K. Jaeger and K.-J. Koch, eds. Trade, Growth and Economic Policy in Open Economies. Springer-Verlag: New York.

Arndt, Sven. (1998b) "Super-Specialization and the Gains from Trade," Contemporary Policy Issues, Western Economic Association, forthcoming.

Arndt, Sven and Henryk Kierzkowski, eds., (2001) Fragmentation: New Production and Trade Patterns in the World Economy, Oxford University Press, Oxford.

Autor, David, Lawrence F. Katz, and Alan B. Krueger, "Computing Inequality: Have Computers Changed the Labor Market?” Quarterly Journal of Economics, 113(4), 11691213.

Baldwin, Robert E. and Cain, Glen G. (1997) "Shifts in U.S. Relative Wages: the Role of Trade, Technology and Factor Endowments,” NBER Working Paper no. 5934.

Baldwin, Robert E. and Hilton, R.S. (1984)“A Technique for Indicating Comparative Costs and Predicting Changes in Trade Ratios," Review of Economics and Statistics, 64, 105-110.

Bartelsman, Eric J. and Wayne Gray (1996) "The NBER Manufacturing Productivity Database," NBER Technical Working Paper no. 205.

Berman, Eli, John Bound, and Zvi Griliches (1994) "Changes in the Demand for Skilled Labor within U.S. Manufacturing: Evidence from the Annual Survey of Manufactures, Quarterly Journal of Economics, 104, 367-398.

Berman, Eli, John Bound, and Stephen Machin (1998) "Implications of Skill-Biased Technological Change: International Evidence," Quarterly Journal of Economics,. 113(8), November, 1245-1280.

Bernard, Andrew B. and J. Bradford Jensen (1997) "Exporters, Skill Upgrading and the Wage Gap," Journal of International Economics, February, 42, 3-32.

Blomstrom, Magnus, Gunnar Fors, and Robert E. Lipsey (1997) "Foreign Direct Investment and Employment: Home Country Evidence in the United States and Sweden," NBER Working Paper No. 6205. 
Bhagwati, Jagdish and Marvin H. Kosters, eds. (1994) Trade and Wages: Leveling Wages Down? Washington, D.C.: American Enterprise Institute.

Blonigen, Bruce and Matthew J. Slaughter (1999) "Foreign-Affiliate Activity and U.S. Skill Upgrading,” NBER Working Paper No. 7040.

Bound, John and George Johnson (1992) "Changes in the Structure of Wages in the 1980s: An Evaluation of Alternative Explanations," American Economic Review, 82, 371-392.

Brainard, S. Lael and David A. Riker (1997) "Are U.S. Multinationals Exporting U.S. Jobs?" NBER Working Paper No. 5958.

Campa, J. and L. Goldberg. (1997) "The Evolving External Orientation of Manufacturing Industries: Evidence from Four Countries,” NBER Working Paper no. 5919; Economic Policy Review, The Federal Reserve Bank of New York, July 1997.

Caves, D. W., Laurits R. Christensen, and W. Erwin Diewert (1982a) "The Economic Theory of Index Numbers and the Measurement of Input, Output and Productivity," Econometrica, 50, 1393-1414.

Caves, D. W., Laurits R. Christensen, and W. Erwin Diewert (1982b) "Multilateral Comparisons of Output, Input, and Productivity Using Superlative Index Numbers, ” Economic Journal, 92, 73-86.

Collins, Susan M., ed. (1998) Imports, Exports, and the American Worker, Washington, D.C.: Brookings Institution Press.

Cragg, M. and Epelbaum, M. (1996) "Why Has Wage Dispersion Grown in Mexico? Is it the Incidence of Reforms or the Growing Demand for Skills?”, Journal of Development Economics 51, 99-116.

Davis, Donald R. and David E. Weinstein (2000) "International Trade as an 'Integrated Equilibrium': New Perspectives,” American Economic Review, 90, 150-154.

Deardorff, Alan V. (2000) "Factor Prices and the Factor Content of Trade Revisited: What's the Use?", Journal of International Economics, 50, 73-90.

Diewert, W.E. (1974), “Applications of Duality Theory,” in Frontiers of Quantitative Economics Vol. II, edited by M. Intriligator and D. Kendrick, North-Holland, Amsterdam, 106-171.

Dicken, Peter, Philip F. Kelley, Kris Olds and Henry Wai-Chung Yeung (2001) "Chains and Networks, Territories and Scales: Towards a Relational Framework for Analyzing the Global Economy," Global Networks, 1(2), 99-123.

Dinopoulos, Elias and Paul Segerstrom (2001) "A Schumpeterian Model of Protection and Real Wages," American Economic Review, 89(3), 450-472. 
Enright, Michael J., Edith E. Scott, and David Dodwell (1997) The Hong Kong Advantage. Hong Kong: Oxford University Press.

Feenstra, Robert C. (1998) "Integration and Disintegration in the Global Economy," Journal of Economic Perspectives, Fall, 31-50.

Feenstra, Robert C. and Gordon H. Hanson. (1996) "Foreign Investment, Outsourcing and Relative Wages," in R.C. Feenstra, G.M. Grossman and D.A. Irwin, eds., The Political Economy of Trade Policy: Papers in Honor of Jagdish Bhagwati, MIT Press, 89-127.

Feenstra, Robert C. and Gordon H. Hanson (1997) "Foreign Direct Investment and Relative Wages: Evidence from Mexico’s Maquiladoras," Journal of International Economics, 42, 371-394.

Feenstra, Robert C. and Gordon H. Hanson (1999) "Productivity Measurement and the Impact of Trade and Technology on Wages: Estimates for the U.S., 1972-1990," Quarterly Journal of Economics, August , 114(3), 907-940.

Feenstra, Robert C. and Gordon H. Hanson (2001) "Intermediaries in Entrepôt Trade: Hong Kong Re-exports of Chinese Goods," National Bureau of Economic Research working paper no. 8088 .

Feenstra, Robert C., Gordon H. Hanson and Deborah L. Swenson (2000) "Offshore Assembly from the United States: Production Characteristics of the 9802 Program," in Robert Feenstra, Editor. The Impact of International Trade on Wages. NBER and University of Chicago Press, 2000, 85-122.

Feliciano, Zadia and Robert E. Lipsey (1999) "Foreign Ownership and Wages in the United States, 1987 - 1992,” NBER Working Paper No. 6923.

Freeman, Richard and Lawrence Katz. (1994) "Rising Wage Inequality: The United States vs. Other Advanced Countries," in Richard Freeman, ed., Working Under Different Rules, New York: Russell Sage Foundation.

Freeman, Richard B., (1995) “Are Your Wages Set in Beijing?” Journal of Economic Perspectives, 9, Summer, 15-32.

Gaston, Noel, and Daniel Trefler (1995) "Union Wage Sensitivity to Trade and Protection: Theory and Evidence," Journal of International Economics, 47, 1-25.

Gereffi, Gary and Miguel Korzeniewicz, eds. (1994) Commodity Chains and Global Capitalism. Westport, Connecticut: Praeger.

Gibbons, Robert and Lawrence Katz (1992) "Does Unmeasured Ability Explain Inter-Industry Wage Differentials?,” Review of Economic Studies, 59, 515-535. 
Glass, Amy Jocelyn and Kamal Saggi (2001) "Innovation and Wage Effects of International Outsourcing," European Economic Review, 45, 67-86.

Görg, Holger (2000) "Fragmentation and Trade: U.S. Inward Processing Trade in the EU," Weltwirtshcaftliches Archiv (Review of World Economics), 136(3), 403-422.

Hanson, Gordon and Harrison, Anne (1999) “Trade, Technology, and Wage Inequality," Industrial and Labor Relations Review 52(2) January, 271-88.

Harrigan, James (2000) "International Trade and American Wages in General Equilibrium, 1967-1995," in Robert C. Feenstra, ed., The Impact of International Trade on Wages, Chicago: University of Chicago Press, 171-193.

Harrigan, James and Rita A. Balaban (1999) "U.S. Wage Effects in General Equilibrium: The Effects of Prices, Technology, and Factor Supplies, 1963-1991," NBER Working Paper No. 6981.

Haskel, Jonathan E. and Matthew J. Slaughter (2000) "Have Falling Tariffs and Transportation Costs Raised U.S. Wage Inequality,” NBER Working Paper No. 7539.

Haskel, Jonathan E. and Matthew J. Slaughter (2001) “Trade Technology and U.K. Wage Inequality," Economic Journal, 110, 1-27.

Head, Keith and John Ries (2000) "Offshore Production and Skill Upgrading by Japanese Manufacturing Firms,” mimeo, University of British Columbia.

Hsieh, Chang-Tai and Keong T. Woo (1999) "The Impact of Outsourcing to China on Hong Kong's Labor Market," mimeo, Princeton University.

Hummels, David, Jun Ishii, and Kei-Mu Yi (2001) "The Nature and Growth of Vertical Specialization in World Trade," Journal of International Economics, 54, 75-96.

Johnson, George and Frank Stafford (1999) “The Labor Market Implications of International Trade," in Orley Ashenfelter and David Card, eds., Handbook of Labor Economics, Vol. 3B, Amsterdam: Elsevier, 2215-2288.

Jones, Ronald (1963) “The Structure of Simple General Equilibrium Models,” Journal of Political Economy, 73, 557-572.

Katz, Lawrence F. and Kevin M. Murphy (1992) "Changes in Relative Wages, 1963-1987: Supply and Demand Factors," Quarterly Journal of Economics, 107, 35-78.

Katz, Lawrence F. and David Autor (1999) "Changes in the Wage Structure and Earnings Inequality," in Orley Ashenfelter and David Card, eds., Handbook of Labor Economics, Vol. 3A, Amsterdam: Elsevier, 1463-1555 
Kohli, U.R. (1978) "A Gross National Product Function and the Derived Demand for Imports and Supply of Exports," Canadian Journal of Economics, 11, 167-82.

Kohli, Ulrich (1991) Technology, Duality and Foreign Trade, Harvester Whetsheaf, London.

Kim, Dae Il and Peter Mieszkowski (1995) "The Effects of International Trade and Outsourcing on Relative Factor Prices," mimeo, Rice University.

Leonard Cheng and Henryk Kierzkowski, eds. (2001) Globalization of Trade and Production in South-East Asia, Kluwer Academic Press, New York, forthcoming.

Krueger, Alan B. (1997) "Labor Market Shifts and the Price Puzzle Revisited," NBER Working Paper no. 5924.

Krueger, Alan B. and Lawrence Summers (1988) "Efficiency Wages and the Inter-Industry Wage Structure," Econometrica, 56, 269-293.

Krugman, Paul (1995) “Growing World Trade: Causes and Consequences,” Brooking Paper on Economic Activity, 1, 327-362.

Krugman, Paul (2000) “Technology, Trade and Factor Prices,” Journal of International Economics, 50(1), 51-72.

Lawrence, R. (1994) “Trade, Multinationals, and Labor,” NBER Working Paper no. 4836.

Lawrence, R. and M. Slaughter. (1993) "International Trade and American Wages in the 1980s: Giant Sucking Sound or Small Hiccup?” Brookings Papers on Economic Activity: Microeconomics, 161-226.

Leamer, Edward E. (1996) "The Effects of Trade in Services, Technology Transfer and Delocalisation on Local and Global Income Inequality," Asia-Pacific Economic Review, 2, 44-60.

Leamer, Edward E. (1998) "In Search of Stolper-Samuelson Linkages between International Trade and Lower Wages," in Susan M. Collins, ed., Imports, Exports, and the American Worker, Washington, D.C.: Brookings Institution Press, 141-203.

Leamer, Edward E. (2000) "What's the Use of Factor Contents?" Journal of International Economics, 50, 17-50.

Lipsey, Robert E. (1994) "Foreign-Owned Firms and U.S. Wages,” NBER Working Paper No. 4927.

Lipsey, Robert E. (1999) "Foreign Production by U.S. Firms and Parent Firm Employment," NBER Working Paper No. 7357. 
Machin, Stephen (1994) "Changes in the Relative Demand for Skills in the United Kingdom Labor Market," forthcoming in Alison Booth and Denis Snower, eds., Acquiring Skills: Market Failures, Their Symptoms and Policy Response, Cambridge: Cambridge University Press.

Machin, Stephen (1996) "Wage Inequality in the UK," Oxford Review of Economic Policy, 12, 47-64.

Marjit, Sugata and Acharyya, R., forthcoming, Trade, Labor and Inequality: A Developing Country Perspective.

Morrison Paul, Catherine and Donald Siegel (2000) “The Impacts of Technology, Trade and Outsourcing on Employment and Labor Compensation," Scandinavian Journal of Economics, forthcoming.

Ng, Francis and Alexander Yeats (1999) "Production Sharing in East Asia: Who Does What for Whom and Why?", mimeo, The World Bank.

Panagariya, Arvind. (2000) "Evaluating the Factor-Content Approach to Measuring the Effect of Trade on Wage Inequality," ?” Journal of International Economics, 50, 91-116.

Riker, D. and S. Brainard. (1997) "U.S. Multinationals and Competition from Low Wage Countries,” NBER Working Paper no. 5959.

Robertson, Raymond (2000) "Relative Prices and Wage Inequality: Evidence from Mexico," mimeo, Macalester College.

Rodrik, D. (1997) Has Globalization Gone Too Far? Institute for International Economics: Washington, D.C..

Sachs, Jeffrey D. and Howard J. Shatz (1994) "Trade and Jobs in U.S. Manufacturing," Brookings Papers on Economic Activity, 1, 1-84.

Sachs, Jeffrey D. and Howard J. Shatz (1998) "International Trade and Wage Inequality: Some New Results," in Susan M. Collins, ed., Imports, Exports, and the American Worker, Washington, DC: Brookings Institution Press, 215-240.

Slaughter, Matthew J. (2000a) "What Are the Results of Product-Price Studies and What Can We Learn from Their Differences?" in Robert C. Feenstra, ed., The Effects of International Trade on Wages, Chicago: University of Chicago Press, 129-165.

Slaughter, Matthew J. (2000b) "Production Transfer within Multinational Enterprises and American Wages,” Journal of International Economics, 50, 449-472. 
Slaughter, Matthew J. (2001) "International Trade and Labor-Demand Elasticities," Journal of International Economics, 54, 27-56.

Stolper, Wolfgang and Paul A. Samuelson (1941) "Protection and Real Wages," Review of Economic Studies, November, 51-68.

Sung, Yun-Wing (1997) "Hong Kong and the Economic Integration of the China Circle." In Naughton, ed., The China Circle. Washington, DC: Brookings Institution Press.

Tombazos, Christis G. (1999) "The Role of Imports in Expanding the Demand Gap Between Skilled and Unskilled Labor in the U.S.," Applied Economics, 31, 509-516.

Trefler, Daniel, (1995) "The Case of Missing Trade and Other Mysteries," American Economic Review, 85, 1029-1046.

Trefler, Daniel and Susan Chun Zhu, (2000) "Beyond the Algebra of Explanation: HOV for the Technology Age," American Economic Review, 90, 145-149.

$\mathrm{Xu}$, Bin (2000) "The Relationship between Outsourcing and Wage Inequality under SectorSpecific FDI Barriers," mimeo, University of Florida.

Yi, Kei-Mu (2000) "Can Vertical Specialization Explain the Growth of World Trade?" Federal Reserve Bank of New York Staff Report No. 96.

Zhu, Susan Chun (2001a) "Trade, Product Cycles and Inequality Within and Between Countries," University of Toronto, mimeo.

Zhu, Susan Chun (2001b) "Product Cycles and Skill Upgrading: An Empirical Assessment," University of Toronto, mimeo. 
Table 1. Share of Imported to Total Intermediate Inputs (Percent)

Country 1974 1984 1993

All Manufacturing Industries

$\begin{array}{lccc}\text { Canada } & 15.9 & 14.4 & 20.2 \\ \text { Japan } & 8.2 & 7.3 & 4.1 \\ \text { United Kingdom } & 13.4 & 19.0 & 21.6 \\ \text { United States } & 4.1 & 6.2 & 8.2\end{array}$

Chemical and Allied Products

$\begin{array}{lccc}\text { Canada } & 9.0 & 8.8 & 15.1 \\ \text { Japan } & 5.2 & 4.8 & 2.6 \\ \text { United Kingdom } & 13.1 & 20.6 & 22.5 \\ \text { United States } & 3.0 & 4.5 & 6.3\end{array}$

\section{Industrial Machinery (Non-electrical)}

$\begin{array}{lccc}\text { Canada } & 17.7 & 21.9 & 26.6 \\ \text { Japan } & 2.1 & 1.9 & 1.8 \\ \text { United Kingdom } & 16.1 & 24.9 & 31.3 \\ \text { United States } & 4.1 & 7.2 & 11.0\end{array}$

Canada

Electrical Equipment and Machinery

Japan

United Kingdom

United States

Canada

Japan

United Kingdom

United States
13.2

3.1

14.9

4.5
17.1

3.4

23.6

6.7

30.9

2.9

34.6

11.6

Transportation Equipment

29.1

1.8

14.3

6.4
37.0

2.4

25.0

10.7
49.7

2.8

32.2

15.7

Note: U.S. estimates are for 1975, 1985, and 1995.

Source: Campa and Goldberg (1997, Tables 1,3,5,7). 
Table 2. Employment -Weighted Percentage Changes in Domestic and Import Prices

Domestic Price

Import Prices

United States (1980-89)

All manufacturing industries

Nonproduction labor weights

33.1

26.0

Production labor weights

32.3

28.1

$\underline{\text { Japan }(1980-90)}$

All manufacturing industries

Nonproduction labor weights $\quad-5.60$

$-18.23$

Production labor weights

- Without Office Machines

Nonproduction labor weights

Production labor weights

- Also without Petroleum Products

Nonproduction labor weights

$-6.98$

$-18.45$

Production labor weights

Germany (1980-90)

All manufacturing industries

Non-manual labor weights $\quad 23.98$

Manual labor weights

- Without Office Machines

Non-manual labor weights $\quad 24.79$

Manual labor weights

- Also without Petroleum Products

Non-manual labor weights

24.97

15.70

Manual labor weights

26.28

17.24

Note: The averages shown weigh each industry's price change by that industry's share of total manufacturing employment or nonproduction and non-manual workers, or production and manual workers. Industries are defined at the 3-digit SIC level for the U.S., and generally correspond to the 2-digit level for Japan and Germany.

Sources: Lawrence and Slaughter (1993, Tables 3 and 4) and Lawrence (1994, Table 4). 
Table 3. Decomposition of the Change in the Share of Employment And Wages of Non-Production Workers, 1973-79 and 1979-87

\section{A. Industry Level Decomposition (percent)}

\begin{tabular}{lccccc} 
Year & \multicolumn{2}{c}{ Employment } & \multicolumn{2}{c}{ Wages } \\
\hline & Between & Within & Between & Within \\
1973-79 & 0.121 & & 0.199 & 0.119 & 0.212 \\
Total & & 0.320 & & \multicolumn{2}{c}{0.381} \\
1979-1987 & 0.184 & \multicolumn{2}{c}{0.362} & 0.309 & \multicolumn{2}{c}{0.410} \\
Total & & 0.546 & & \multicolumn{2}{c}{0.719}
\end{tabular}

\section{B. Plant Level Decomposition (percent)}

\begin{tabular}{|c|c|c|c|c|}
\hline Year & \multicolumn{2}{|c|}{ Employment } & \multicolumn{2}{|c|}{ Wages } \\
\hline & Between & Within & Between & Within \\
\hline $1973-79$ & 0.101 & 0.170 & 0.140 & 0.134 \\
\hline Total & \multicolumn{2}{|c|}{0.271} & \multicolumn{2}{|c|}{0.274} \\
\hline $1979-1987$ & 0.177 & 0.215 & 0.315 & 0.221 \\
\hline Total & \multicolumn{2}{|c|}{0.392} & \multicolumn{2}{|c|}{0.536} \\
\hline
\end{tabular}

Note:

Numbers are percentage changes between years. Between numbers represent shifts across 4digit SIC industries in part A, and shifts across plants in part B. Within numbers represent changes within industries in part A, and within plants in part B. All calculations have been annualized.

Sources:

Part A from Berman, Bound and Griliches (1993), and part B from Bernard and Jensen (1997). 
Table 4: Dependent Variable - Change in Nonproduction Wage Share, 1979-1990

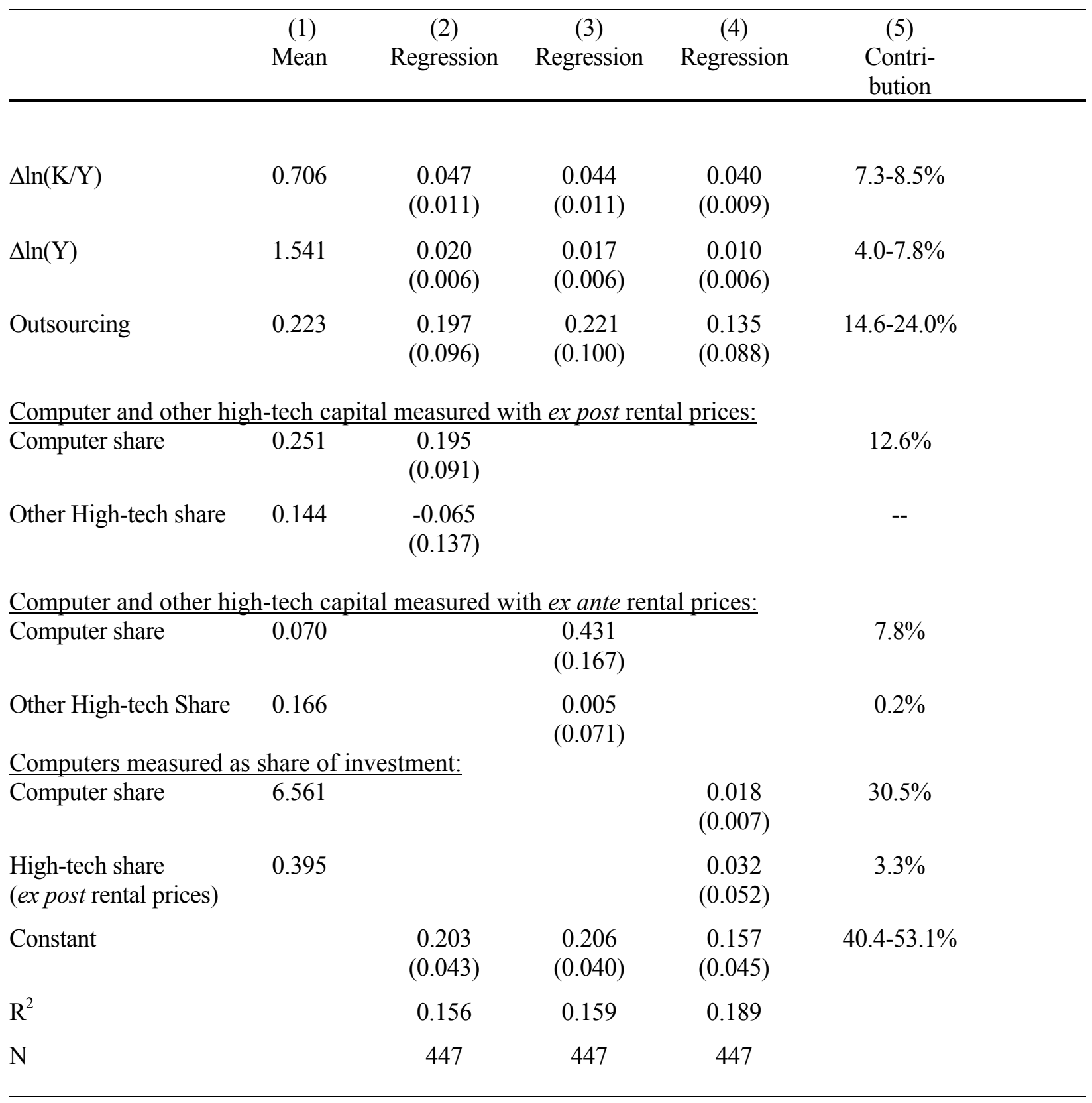

Note: The mean of the dependent variable equals 0.389. Standard errors (in parentheses) are robust to heteroskedasticity and correlation in the errors within two-digit industries. The first column shows mean values of the dependent and independent variables for 1979-1990. All regressions and means are computed over 447 four-digit SIC industries and are weighted by the average industry share of the manufacturing wage bill. $\Delta \ln (\mathrm{K} / \mathrm{Y})$ is the average annual change in the log capital-shipments ratio and $\Delta \ln (\mathrm{Y})$ is the average annual change in log real shipments. The outsourcing variables and the computer and hightechnology shares are in annual changes. 
Table 5: Dependent Variable - Log Change in Industry Price, 1979-1990

\begin{tabular}{lccccc}
\hline & $(1)$ & $(2)$ & $(3)$ & $(4)$ & $(5)$ \\
\hline Effective TFP & & & & -1.00 & -1.00 \\
& & & & $(0.007)$ & $(0.001)$ \\
TFP & -0.96 & -0.75 & & & \\
& $(0.07)$ & $(0.08)$ & & & \\
Production & 3.06 & 2.43 & 3.61 & 4.68 & 4.70 \\
cost-share & $(1.22)$ & $(1.16)$ & $(1.89)$ & $(0.02)$ & $(0.01)$ \\
Nonproduction & 2.30 & 4.09 & 6.20 & 5.48 & 5.44 \\
cost-share & $(1.43)$ & $(1.72)$ & $(4.04)$ & $(0.02)$ & $(0.03)$ \\
$\begin{array}{l}\text { Capital } \\
\text { cost-share }\end{array}$ & 7.89 & 8.06 & 9.54 & 3.95 & 3.97 \\
Materials cost-share times & $1.00 *$ & $1.00^{*}$ & 1.22 & $1.00^{*}$ & 1.00 \\
change in materials price & & & $(0.25)$ & & $(0.002)$ \\
$\begin{array}{l}\text { Energy cost-share times } \\
\text { change in energy price }\end{array}$ & $1.00^{*}$ & $1.00^{*}$ & -0.93 & $1.00^{*}$ & 1.00 \\
constant & & & $(0.92)$ & & $(0.006)$ \\
& -0.71 & -0.83 & -1.93 & & 0.01 \\
$\mathrm{R}^{2}$ & $(0.30)$ & $(0.29)$ & $(0.92)$ & & $(0.005)$ \\
$\mathrm{N}$ & 0.896 & 0.806 & 0.429 & 0.999 & 0.999 \\
& 447 & 446 & 446 & 447 & 447 \\
\hline
\end{tabular}

Note: Standard errors are in parentheses. All regressions omit three industries with missing data on materials purchases or prices (SIC 2067, 2794, 3483) and are weighted by the industry share of total manufacturing shipments, averaged over the first and last period.

In columns (1)-(3) and (5), the dependent variable is the log change in the gross industry price, and the factor cost shares sum to one across all factors. The materials cost share is multiplied by the log change in the materials price; the energy cost share is treated similarly. In column (4), the dependent variable is the log change in the industry value-added price and factor cost shares sum to one across primary factors. Column (1) uses primal TFP as a regressor; column (2) drops the computer industry (SIC 3573) from the sample; column (3) also drops TFP as a regressor; and column (5) uses effective TFP as a regressor, where effective TFP equals primal TFP minus the change in wage differentials.

* These coefficients are constrained at unity.

Source: Feenstra and Hanson (1999). 

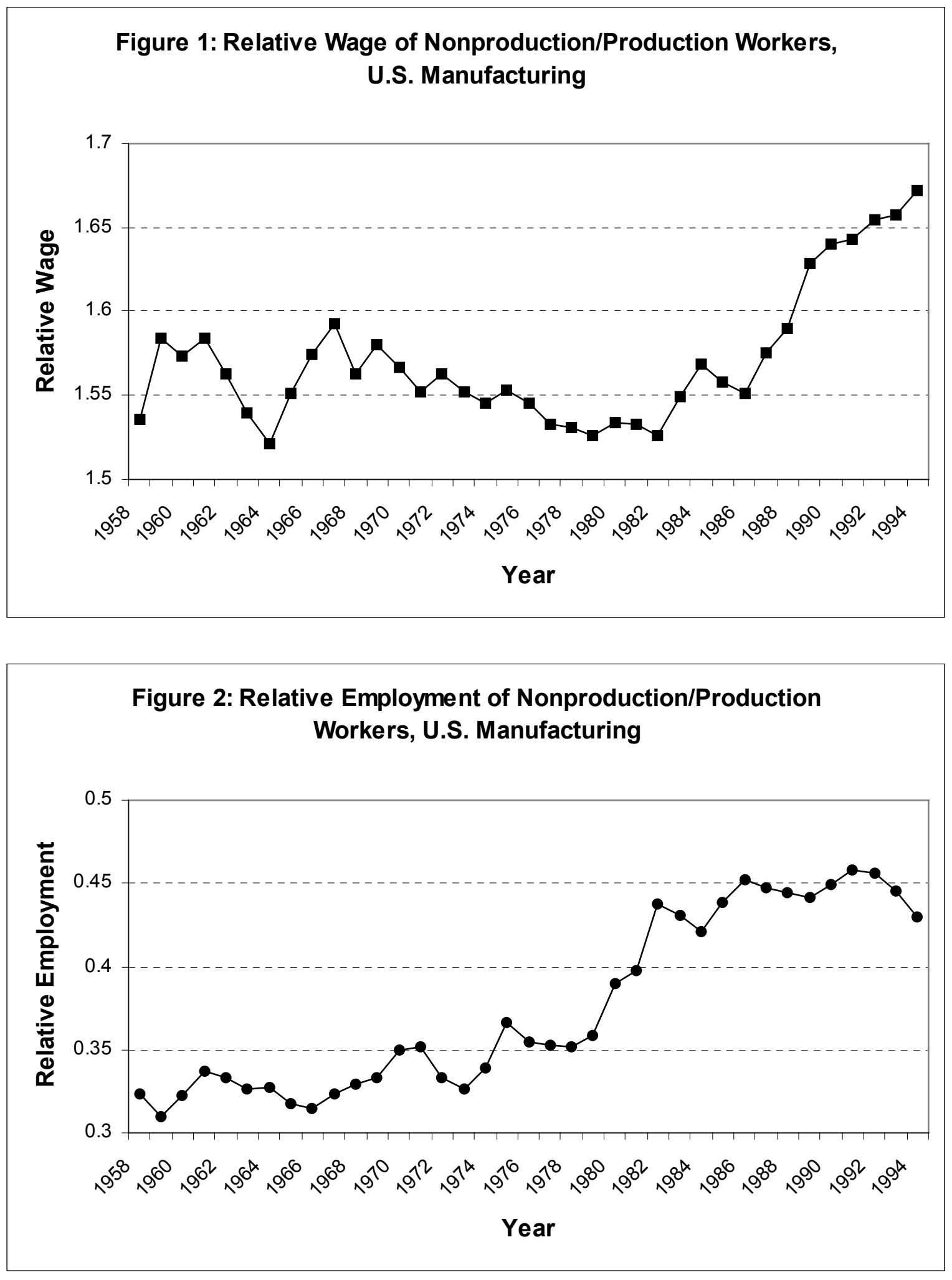


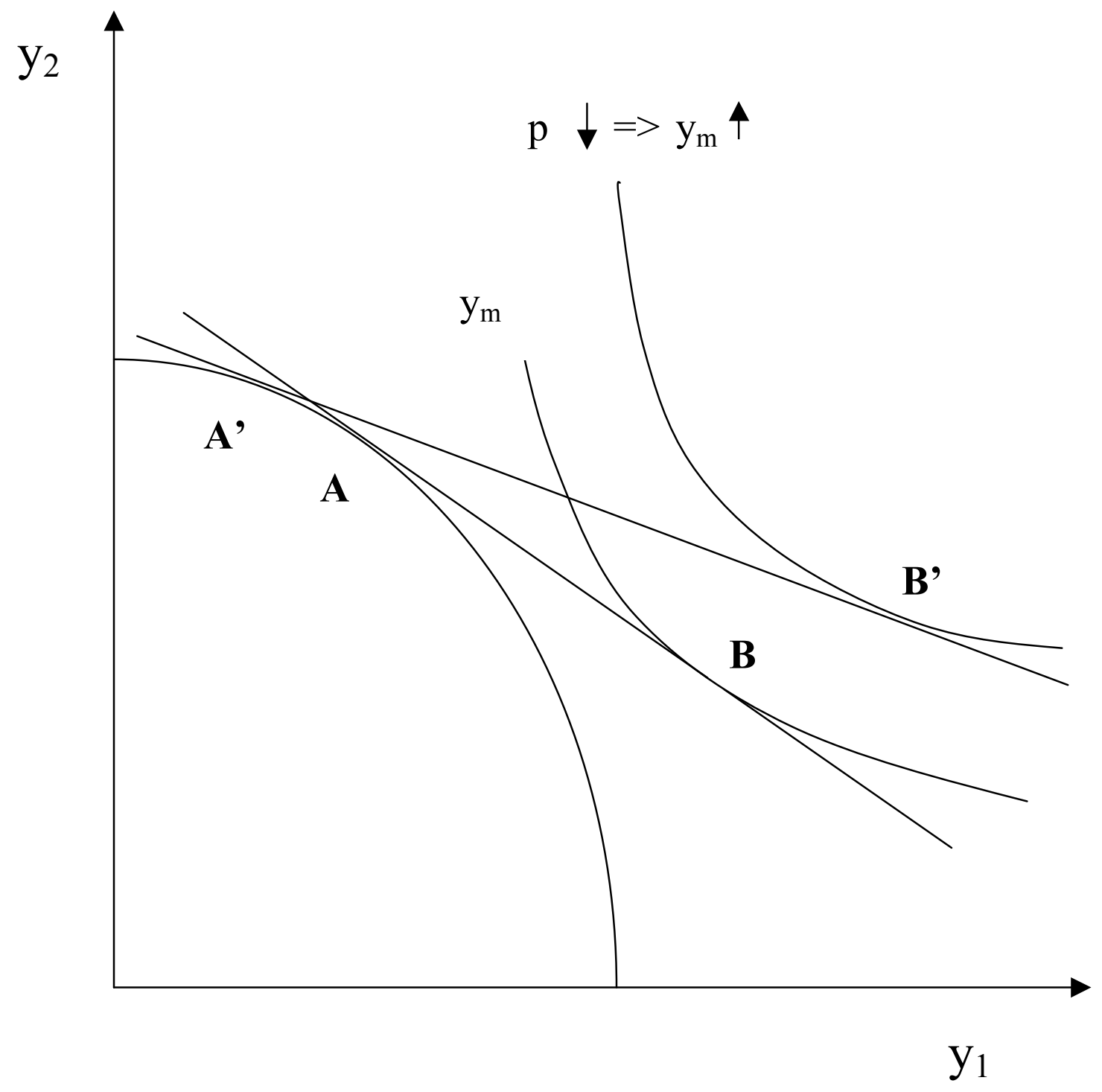

Figure 3: Production of industry output $\mathrm{y}_{\mathrm{m}}$ 


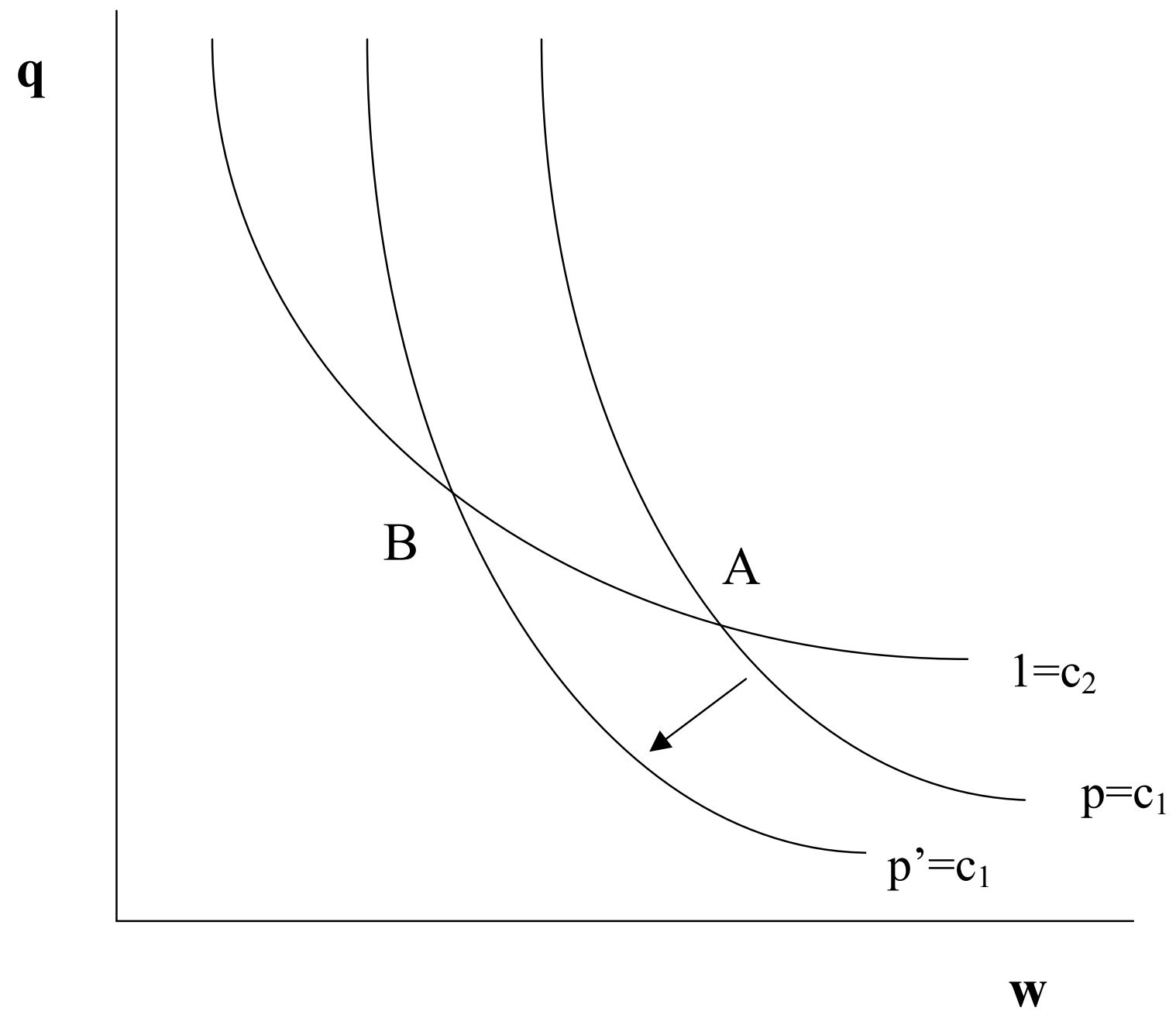

Figure 4: Change in wages due to a fall in $\mathrm{p}$ 


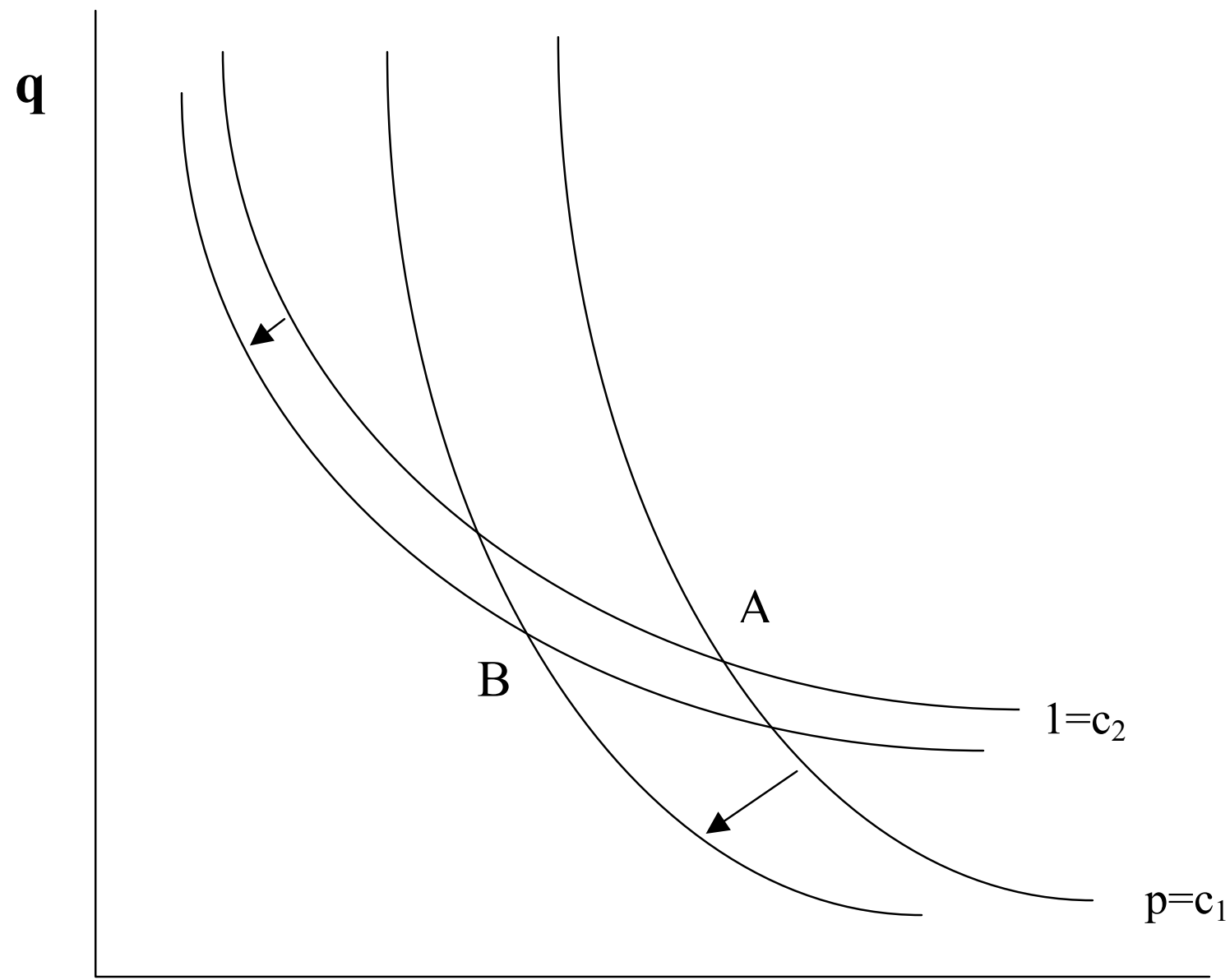

W

Figure 5: Change in wages due to a rise in $r$ 